\title{
Conformational Flexibility, UV-Induced Decarbonylation, and FTIR Spectra of 1-Phenyl-1,2 Propanedione in Solid Xenon and in the Low Temperature Amorphous Phase
}

\author{
Susy Lopes, ${ }^{\dagger}$ Andrea Gómez-Zavaglia, ${ }^{\dagger, *}$ Leszek Lapinski, ${ }^{\S}$ and Rui Fausto ${ }^{*, \dagger}$ \\ Department of Chemistry, University of Coimbra, P-3004-535 Coimbra, Portugal, Faculdad de Farmacia y \\ Bioquímica, Universidad de Buenos Aires, Junín 956, 1113 Buenos Aires, Argentina, and Institute of Physics of \\ the Polish Academy of Sciences, Al. Lotnikow 32/46, 02-668 Warsaw, Poland
}

Received: December 15, 2004; In Final Form: March 14, 2005

\begin{abstract}
1-Phenyl-1,2-propanedione has been isolated in low-temperature xenon matrixes and studied by FTIR spectroscopy, supported by DFT(B3LYP)/6-311++G(d,p) calculations. In good agreement with previous electron diffraction data [Shen, Q.; Hagen, K. J. Phys. Chem. 1993, 97, 985], the calculations predicted the existence of only one stable conformation for the compound, in which the $\mathrm{O}=\mathrm{C}-\mathrm{C}=\mathrm{O}$ dihedral angle is $135.6^{\circ}$. On the other hand, the experimental data clearly reveals that, in the as-deposited xenon matrixes $(T=20 \mathrm{~K})$, there is a distribution of molecules with different $\mathrm{O}=\mathrm{C}-\mathrm{C}=\mathrm{O}$ dihedral angles around the equilibrium value. This distribution results from the efficient trapping of the conformational distribution existing in the gas phase, prior to deposition, which is determined by the low frequency, large amplitude torsional vibration around the $\mathrm{C}-\mathrm{C}$ central bond. Upon annealing to higher temperatures $(T \sim 45 \mathrm{~K})$, the initially trapped conformational distribution can be modified in a certain degree, favoring more polar structures (corresponding to smaller $\mathrm{O}=\mathrm{C}-\mathrm{C}=\mathrm{O}$ dihedral angles), as a result of the interactions with the matrix media. Irradiation of the matrix with UV light $(\lambda>235 \mathrm{~nm})$ led to decarbonylation of the compound, with generation of acetophenone and carbon monoxide, with an almost complete consumption of the reagent after 1100 min of irradiation $\left(k=2.8 \times 10^{-2} \mathrm{~min}^{-1}\right)$. Aggregation of the compound resulting from the matrix warming was also investigated, providing useful information for interpretation of the spectroscopic data obtained for the low-temperature amorphous state of the neat compound.
\end{abstract}

\section{Introduction}

$\alpha$-Dicarbonyl compounds have been the subject of extensive research due to their important applications. ${ }^{1-4}$ 1-Phenyl-1,2propanedione (PPD) receives practical use as photosensitizer for photopolymerization of visible light-cured dental resin composites $^{5-7}$ and as photoinitiator for the photo-cross-linking of waterborne latex paints, ${ }^{8}$ being also a common reactant in asymmetric synthesis. ${ }^{9-27}$ Enantioselective hydrogenation of PPD has been used for production of $\alpha$-hydroxy carbonyl compounds and diols, ${ }^{9-27}$ which are utilized in the synthesis of many biologically relevant substances, such as, for example, ephedrine and pseudoephedrine. ${ }^{28-30}$ The conditions to carry out this reaction have been the matter of several reports: it has been performed using heterogeneous catalysis in different solvents, oxygenation conditions and in the presence or absence of ultrasonic irradiation, ${ }^{9-21}$ by using bakers yeast as reducing agent, ${ }^{22-25}$ pollarographically, ${ }^{26}$ and metabolically in vivo. ${ }^{27}$ PPD has also been used, together with methylguanidine, as reagents to produce $4 \mathrm{H}$-imidazole rings. ${ }^{31}$

From a more fundamental point of view, $\alpha$-dicarbonyl compounds have deserved much attention due to the photorotamerism they frequently exhibit. ${ }^{32-37}$ These compounds have been found to be considerably flexible, and the large amplitude, low-frequency vibrational mode associated with the $\mathrm{O}=\mathrm{C}-\mathrm{C}=$ $\mathrm{O}$ torsional coordinate has been shown to influence significantly

\footnotetext{
* Corresponding author. E-mail: rfausto@ci.uc.pt.

$\dagger$ University of Coimbra.

$\doteqdot$ Universidad de Buenos Aires.

$\S$ Institute of Physics of the Polish Academy of Sciences.
}

their physicochemical properties. ${ }^{38-42}$ In a large number of $\alpha$-dicarbonyl compounds, a long wavelength $n-\pi *$ transition occurs at $\lambda_{\max }$ in the range $420-500 \mathrm{~nm}$ for both cis and trans coplanar dicarbonyl arrangements, shifting to substantially higher energies $\left(\lambda_{\max }<400 \mathrm{~nm}\right)$ whenever the intercarbonyl dihedral angle deviates significantly from the planarity. ${ }^{32,43-47}$ Benzil $\left[\mathrm{C}_{6} \mathrm{H}_{5} \mathrm{C}(=\mathrm{O}) \mathrm{C}(=\mathrm{O}) \mathrm{C}_{6} \mathrm{H}_{5} ;\right.$ 1,2-diphenyl-ethanedione] and PPD are examples of simple $\alpha$-dicarbonyl compounds showing this characteristic behavior. ${ }^{36,37,39-42,47}$ In a spectroscopic study on PPD and other propanediones, Arnett et al. ${ }^{37}$ demonstrated that excitation of propanedione molecules with an $\mathrm{O}=\mathrm{C}-\mathrm{C}=$ $\mathrm{O}$ planar conformation is more efficient in the induction of luminescence than excitation of twisted species. Since all known $\alpha$-dicarbonyls emit only from the planar (or nearly planar) dicarbonyl geometric configurations, those authors concluded that a twisted $\mathrm{O}=\mathrm{C}-\mathrm{C}=\mathrm{O}$ angle favors energy dissipation processes depopulating $\mathrm{S}_{1}$ and $\mathrm{T}_{1}$ states. These processes are responsible for the weak luminescence of the twisted compounds. ${ }^{37}$

Experimental structural studies on PPD have been carried out only for the compound in the gaseous phase, by electron diffraction. ${ }^{43}$ According to the electron diffraction analysis, PPD is a nonplanar molecule with the $\mathrm{O}=\mathrm{C}-\mathrm{C}=\mathrm{O}$ torsional angle of $129.9^{\circ}$ and the phenyl ring nearly coplanar with the vicinal carbonyl group. No evidence of presence in the gaseous phase of a second conformer was found. Comparison of the $\mathrm{O}=\mathrm{C}-$ $\mathrm{C}=\mathrm{O}$ torsion angle in diacetyl $\left(\mathrm{CH}_{3} \mathrm{COCOCH}_{3} ; 2,3\right.$-butanedione: $\left.180^{\circ 38,49}\right)$, benzil $\left(106.6^{\circ 39,50}\right)$, and PPD $\left(129.9^{\circ 43}\right)$ clearly demonstrates that the presence of a phenyl group destabilizes 
the planar anti form $\left(\mathrm{O}=\mathrm{C}-\mathrm{C}=\mathrm{O}\right.$ angle equals to $\left.180^{\circ}\right)$, because of the steric hindrance between this group and the carbonyl moiety.

Structure of PPD molecules in a vacuum and in different solvents was also studied previously by quantum chemical calculations at both $\mathrm{HF} / 6-31+\mathrm{G}(\mathrm{d}, \mathrm{p})$ and DFT(B3LYP)/6$31+\mathrm{G}(\mathrm{d}, \mathrm{p})$ levels of theory. ${ }^{9,10}$ These theoretical studies predicted values for the $\mathrm{O}=\mathrm{C}-\mathrm{C}=\mathrm{O}$ dihedral angle in the minimum energy conformation of PPD ranging from $120.1^{\circ}$ (DFT(B3LYP)/6-31+G(d,p) in methanol) to $154.0^{\circ}$ (DFT(B3LYP)/6-31+G(d,p) in a vacuum). To our knowledge, no other calculations on this compound were reported hitherto.

Previous studies carried out in our laboratory have demonstrated that the movement along the low frequency, large amplitude $\tau \mathrm{O}=\mathrm{C}-\mathrm{C}=\mathrm{O}$ torsional coordinate in both benzil and diacetyl is strongly influenced by temperature and phase and extremely sensitive to the chemical environment. These properties are of particular importance in determining the conformational, structural, and vibrational features of these two molecules, including their excited state conformational preferences. ${ }^{38,39}$ The investigation of $\mathrm{PPD}(\mathrm{O}=\mathrm{C}-\mathrm{C}=\mathrm{O}$ moiety bounded to one methyl and one phenyl group), which represents an intermediate species between diacetyl $(\mathrm{O}=\mathrm{C}-\mathrm{C}=\mathrm{O}$ bounded to two methyl groups) and benzil $(\mathrm{O}=\mathrm{C}-\mathrm{C}=\mathrm{O}$ bounded to two phenyl groups $)$ appears as a natural development of our studies on the structure and spectroscopic properties of simple $\alpha$-dicarbonyl compounds. Thus, in the present study, we applied the same methodology used in our previous studies on diacetyl and benzil ${ }^{38,39}$ to the investigation of PPD. The compound, in both the low-temperature neat solid state and isolated in low-temperature inert matrixes, was studied by FTIR spectroscopy. Advantage is taken of the unique characteristics of FTIR matrix-isolation spectroscopy, such as high intrinsic spectral resolution and high sensitivity to conformational changes. The interpretation of the experimental results is supported by extensive high-level theoretical calculations.

Results of in situ irradiation of the matrixes with UV light $(\lambda>235 \mathrm{~nm})$, leading to photodegradation of the compound with evolution of carbon monoxide, were also investigated, as well as aggregation of the compound resulting from the matrix warming. These latter provide useful information for interpretation of the spectroscopic data obtained for the low-temperature amorphous state of the neat compound. Note that suppliers alert that the hazardous decomposition of PPD can produce carbon monoxide, but there are no available data regarding ecotoxicity and environmental fate of PPD. Due to the dangerous effects of carbon monoxide on human and animal health, ${ }^{51-54}$ the study of the decomposition reactions of PPD, under adequate experimental conditions, appeared to be essential for optimization of its manipulation and successful practical applications. The matrix-isolation spectroscopy is certainly an adequate method to attain this goal, because no strong interactions between the compound and the inert matrix are expected. In addition, the circumstance that the photochemical processes in a matrix are confined to the matrix cage preclude the undesirable sidereactions that can easily occur under other experimental conditions.

\section{Materials and Methods}

Infrared Spectroscopy. The sample of 1-phenyl-1,2-propanedione (99\% purity) was obtained from Aldrich.

The IR spectra were recorded with $0.5 \mathrm{~cm}^{-1}$ spectral resolution using a Mattson (Infinity 60AR Series) Fourier Transform infrared spectrometer, equipped with a deuterated triglycine sulfate (DTGS) detector and a $\mathrm{Ge} / \mathrm{KBr}$ beam splitter. Necessary modifications of the sample compartment of the spectrometer were done in order to accommodate the cryostat head and allow purging of the instrument by a stream of pretreated dry air to remove water vapors and $\mathrm{CO}_{2}$. The liquid sample of PPD was placed in a specially designed doubly termostattable Knudsen cell. ${ }^{55}$ Matrixes were prepared by codeposition of PPD vapors coming out of the Knudsen cell and large excess of the matrix gas (xenon, $99.995 \%$, obtained from Air Liquide) onto the CsI substrate of the cryostat (APD Cryogenics, model DE-202A), cooled to $20 \mathrm{~K}$. To avoid association during deposition, the sample was kept into a water: acetone $2: 1$ cryogenic mixture (temperature $=243 \mathrm{~K}$ ), whereas the temperature of the vapors of the compound before deposition was, in all experiments, $298 \mathrm{~K}$. After depositing the compound, annealing of the matrixes was performed up to $70 \mathrm{~K}$.

The low temperature solid amorphous layer was prepared in the same way as matrixes but with the flux of matrix gas cut off. The layer was then allowed to anneal at slowly increasing temperature up to $215 \mathrm{~K}$. After the temperature exceeded 215 $\mathrm{K}$, the crystallization of the amorphous layer occurred. Subsequently, the CsI substrate was cooled back to $9 \mathrm{~K}$, and spectrum of the crystalline phase was collected.

Irradiation of the matrixes was undertaken through the outer $\mathrm{KBr}$ window of the cryostat $(\lambda>235 \mathrm{~nm})$, with unfiltered light from a $150 \mathrm{~W}$ xenon arc lamp (Osram XBO 150W/CR OFR).

Computational Methodology. The quantum chemicalcalculations were performed with Gaussian 98 (revision A.9) $\operatorname{program}^{56}$ at the DFT level of theory, using the triple- $\zeta$ $6-311++\mathrm{G}(\mathrm{d}, \mathrm{p})$ basis set and the three-parameter density functional abbreviated as B3LYP, which includes Becke's gradient exchange correction ${ }^{57}$ and the Lee, Yang, and Parr correlation functional. ${ }^{58}$

Geometrical parameters of the considered conformations were optimized using the geometry direct inversion of the invariant subspace (GDIIS) method. ${ }^{59}$ To assist the analysis of the experimental spectra, vibrational frequencies and IR intensities were also calculated at the same level of approximation. The computed harmonic frequencies were scaled down by a single factor (0.978) to correct them for the effects of basis set limitations, the neglected part of electron correlation, and anharmonicity effects. Relaxed potential energy torsional profiles were also obtained at the same level of theory. In these calculations, all geometrical parameters except the $\mathrm{O}=\mathrm{C}-\mathrm{C}=$ $\mathrm{O}$ torsional angle (fixed at a given value, using increments of $30^{\circ}$ ) were optimized. The energy-weighted average $\mathrm{O}=\mathrm{C}-\mathrm{C}=$ $\mathrm{O}$ dihedral angles and dipole moments, at a given temperature, were estimated using a simple classical model that takes into consideration all significantly populated conformations differing in the $\mathrm{O}=\mathrm{C}-\mathrm{C}=\mathrm{O}$ torsional angle. The applied procedure follows the method previously described by Gómez-Zavaglia and Fausto. ${ }^{38}$ Normal coordinate analysis was undertaken in the internal coordinates space, as described by Schachtschneider, ${ }^{60}$ using the program BALGA and the optimized geometries and harmonic force constants resulting from the DFT(B3LYP)/ 6-311++G(d,p) calculations.

\section{Results and Discussion}

Geometries and Energies. The optimized geometry of PPD is displayed in Figure 1. In agreement with the available electron diffraction results, ${ }^{43}$ the calculations performed in this study predicted the existence of only one stable conformation for the compound, in which the $\mathrm{O}=\mathrm{C}-\mathrm{C}=\mathrm{O}$ dihedral angle is $135.6^{\circ}$ ( $C_{1}$ symmetry point group). The calculated bond lengths and 


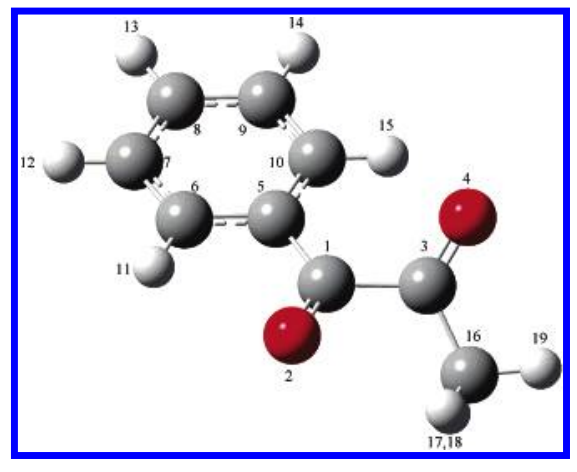

Figure 1. Minimum energy conformation of $\mathrm{PPD}\left(\mathrm{C}_{1}\right.$ symmetry; $\mathrm{O}=\mathrm{C}-\mathrm{C}=\mathrm{O}$ dihedral angle: $135.6^{\circ}$ ) with atom numbering.

angles are given in Table S1 (Supporting Information), together with the previously obtained electron diffraction data ${ }^{43}$ and lower level DFT(B3LYP)/6-31+G(d,p) theoretical results. ${ }^{9}$ As it can be seen, the three sets of data show a good general agreement, though the agreement between the present calculations and the experimental results is much better than that between the lower level calculations reported by Toukoniitty et al. ${ }^{9}$ and the experiment in what concerns the $\mathrm{O}=\mathrm{C}-\mathrm{C}=\mathrm{O}$ dihedral angle (experimental: $129.9^{\circ}$; present calculations: $135.6^{\circ}$; previous DFT(B3LYP)/ 6-31+G(d,p) theoretical results: $\left.154.0^{\circ}\right)$.

It is interesting to compare the relative values of the different $\mathrm{C}-\mathrm{C}$ bond lengths in the PPD molecule. As expected, the $\mathrm{C}-\mathrm{C}$ bonds of the aromatic ring are the shortest ones, with bond lengths ranging from 138.8 to $140.5 \mathrm{pm}$ (in the electron diffraction study, all $\mathrm{C}-\mathrm{C}$ aromatic bonds were assumed to be equal $^{43}$ ). Among them, the two bonds located closer to the $\mathrm{O}=\mathrm{C}-\mathrm{C}=\mathrm{O}$ moiety were predicted as being the longest ones $\left(\mathrm{C}_{5}-\mathrm{C}_{6}=140.5 \mathrm{pm} ; \mathrm{C}_{5}-\mathrm{C}_{10}=140.3 \mathrm{pm}\right)$. The $\mathrm{C}_{1}-\mathrm{C}_{5}$ bond, connecting the $\mathrm{O}=\mathrm{C}-\mathrm{C}=\mathrm{O}$ group to the phenyl ring, was found to be shorter than $\mathrm{C}_{3}-\mathrm{C}_{16}$, which links the $\mathrm{O}=\mathrm{C}-\mathrm{C}=\mathrm{O}$ and $\mathrm{CH}_{3}$ groups (148.7 vs. $150.6 \mathrm{pm}$; see Table $\mathrm{S} 1$ ), in consonance with the existence in the molecule of some degree of $\pi$-delocalization involving the $\mathrm{O}=\mathrm{C}-\mathrm{C}=\mathrm{O}$ and phenyl groups (hyperconjugation between the methyl and $\mathrm{O}=\mathrm{C}-\mathrm{C}=\mathrm{O}$ groups shall also be operating, ${ }^{61,62}$ but this effect is certainly less important in structural terms than the $\mathrm{O}=\mathrm{C}-\mathrm{C}=\mathrm{O} /$ phenyl conjugation). Note that the $\mathrm{C}_{1}-\mathrm{C}_{5}$ and $\mathrm{C}_{3}-\mathrm{C}_{16}$ bond lengths in PPD were estimated to be as long as the equivalent distances in benzil $\left(148.7 \mathrm{pm}^{39}\right)$ and diacetyl $\left(150.5 \mathrm{pm}^{38}\right)$ predicted at the same level of theory. The longest $\mathrm{C}-\mathrm{C}$ bond in the molecule is the central intercarbonyl $\mathrm{C}-\mathrm{C}$ bond, which is $155.0 \mathrm{pm}$ long, i.e., it has a bond length characteristic of a typical nonconjugated $\mathrm{C}-\mathrm{C}$ single bond. This result follows the same trend already noticed for both diacetyl and benzil, ${ }^{38,39}$ and confirms once again the fact that the $\pi$-conjugation between the two carbonyl groups in the $\mathrm{O}=\mathrm{C}-\mathrm{C}=\mathrm{O}$ fragment is minimal, the dominant forces determining the intercarbonyl $\mathrm{C}-\mathrm{C}$ bond length being those associated with the repulsions between the positively charged carbonyl carbon atoms (acting essentially through the $\sigma$-electron system). This is also in agreement with the experimental observations that show both the large conformational flexibility around the $\mathrm{C}-\mathrm{C}$ intercarbonyl bond in $\alpha$-dicarbonyls (clearly revealing that the contribution of double bond character is minimal) and the relative facility of these molecules to suffer cleavage of this bond [e.g., the bond energies of $\mathrm{C}-\mathrm{C}$ intercarbonyl bond in diacetyl and benzil are only ca. $280 \mathrm{~kJ}$ $\mathrm{mol}^{-1}$, which is quite a small value in comparison, for instance, with the bond energies of the $\mathrm{CH}_{3}-\mathrm{C}$ bond in acetone and acetophenone (ca. 320 and $360 \mathrm{~kJ} \mathrm{~mol}^{-1}$, respectively) or $\mathrm{C}-\mathrm{C}$ bond in ethane $\left.\left(376.0 \mathrm{~kJ} \mathrm{~mol}^{-1}\right)\right] \cdot{ }^{38,39,63-71}$

Since PPD represents an intermediate species between diacetyl and benzil, it is also interesting to compare the length of the $\mathrm{C}-\mathrm{C}$ central bond in these compounds: 155.7, 155.0, and $154.4 \mathrm{pm}$, respectively, for diacetyl, ${ }^{38} \mathrm{PPD}$, and benzil. ${ }^{39}$ The $\mathrm{C}-\mathrm{C}$ bond length in PPD is intermediate between diacetyl and benzil; that is, the results are consistent with those extracted from the electron distribution population analysis, which indicates that the $\sigma$-electron population at the carbonyl carbon atom is lower (i.e., the positive charge on the carbon atom is larger) when it is directly bound to a methyl than to a phenyl group. Hence, the $\sigma$-electron system repulsion between the carbonyl carbon atoms decreases in the order diacetyl/PPD/ benzil, justifying the observed relative intercarbonyl $\mathrm{C}-\mathrm{C}$ distances in the three molecules.

The calculated relative values for the $\mathrm{C}_{1}-\mathrm{C}_{3}=\mathrm{O}_{4} / \mathrm{C}_{3}-\mathrm{C}_{1}=$ $\mathrm{O}_{2}$ and $\mathrm{C}_{3}-\mathrm{C}_{1}-\mathrm{C}_{5} / \mathrm{C}_{1}-\mathrm{C}_{3}-\mathrm{C}_{16}$ pairs of angles in PPD do also deserve here an additional comment. In each pair of angles, the first angle is connected with the phenyl group, whereas the second is connected with the methyl group (see Figure 1). The calculated values for these angles are $120.3^{\circ} / 116.5^{\circ}$ and $120.7^{\circ} \%$ $115.7^{\circ}$; that is, the angles associated with the phenyl group are systematically larger than those associated with the methyl group. This trend is a direct consequence of the more pronounced repulsions between the bigger phenyl group and the carbonyl group in the $\beta$-position to the phenyl moiety $\left(\mathrm{C}_{3}=\mathrm{O}_{4}\right)$ in comparison to those between the methyl and the corresponding $\beta$-carbonyl $\left(\mathrm{C}_{1}=\mathrm{O}_{2}\right)$. It is worth mentioning that the pattern exhibited by the electron diffraction data concerning these angles is different, with the $\mathrm{C}_{1}-\mathrm{C}_{3}-\mathrm{C}_{16}$ angle being the largest angle. Indeed, this angle differs by ca. $6^{\circ}$ from the calculated value $\left(121.4^{\circ}\right.$ vs $\left.115.7^{\circ}\right)$. Such a pattern is, however, difficult to justify, and with all probability, the experimental value for the $\mathrm{C}_{1}-$ $\mathrm{C}_{3}-\mathrm{C}_{16}$ is in error.

The potential energy profile obtained at the DFT(B3LYP)/ $6-311++G(d, p)$ level for the internal rotation around the central $\mathrm{C}-\mathrm{C}$ bond in PPD is shown in Figure 2a. Two energy barriers separate the symmetry-equivalent minima. The barrier with maximum at the cis $\mathrm{O}=\mathrm{C}-\mathrm{C}=\mathrm{O}$ conformation is as high as $36.4 \mathrm{~kJ} \mathrm{~mol}^{-1}$, whereas that corresponding to the trans conformation is only $3.3 \mathrm{~kJ} \mathrm{~mol}^{-1}$. This large difference in the energy barriers could be easily anticipated, since for the cis conformation the conjugated effect of the repulsions between the phenyl and the methyl groups, in one side of the molecule, and between the oxygen lone electron pairs, in the other side, strongly destabilizes this conformation. On the other hand, for the trans conformation, the steric repulsions (phenyl $\cdots \mathrm{O}_{4}=\mathrm{C}_{3}$ and methyl $\cdots \mathrm{O}_{2}=\mathrm{C}_{1}$ ) are partially compensated by the favorable electrostatic attractive forces between the interacting groups in both sides of the molecule.

From Figure 2a, it can also be concluded that around the minimum energy conformation the potential energy grows faster changing the $\mathrm{O}=\mathrm{C}-\mathrm{C}=\mathrm{O}$ dihedral toward the cis conformation than in the direction of the trans conformation (for example, upon internal rotation in the direction of the cis conformation, a relative energy equal to that of the trans conformation is attained for a $\mathrm{O}=\mathrm{C}-\mathrm{C}=\mathrm{O}$ dihedral angle of ca. $106^{\circ}$; that is, the changes in the dihedral angle counted from the equilibrium geometry correspond then to ca. $29^{\circ}$ and $45^{\circ}$, respectively moving toward the cis and trans structure). Assuming a model where the large amplitude, low-frequency torsion around the central $\mathrm{C}-\mathrm{C}$ bond is treated classically, and calculating the number of molecules of PPD with a given conformation around 


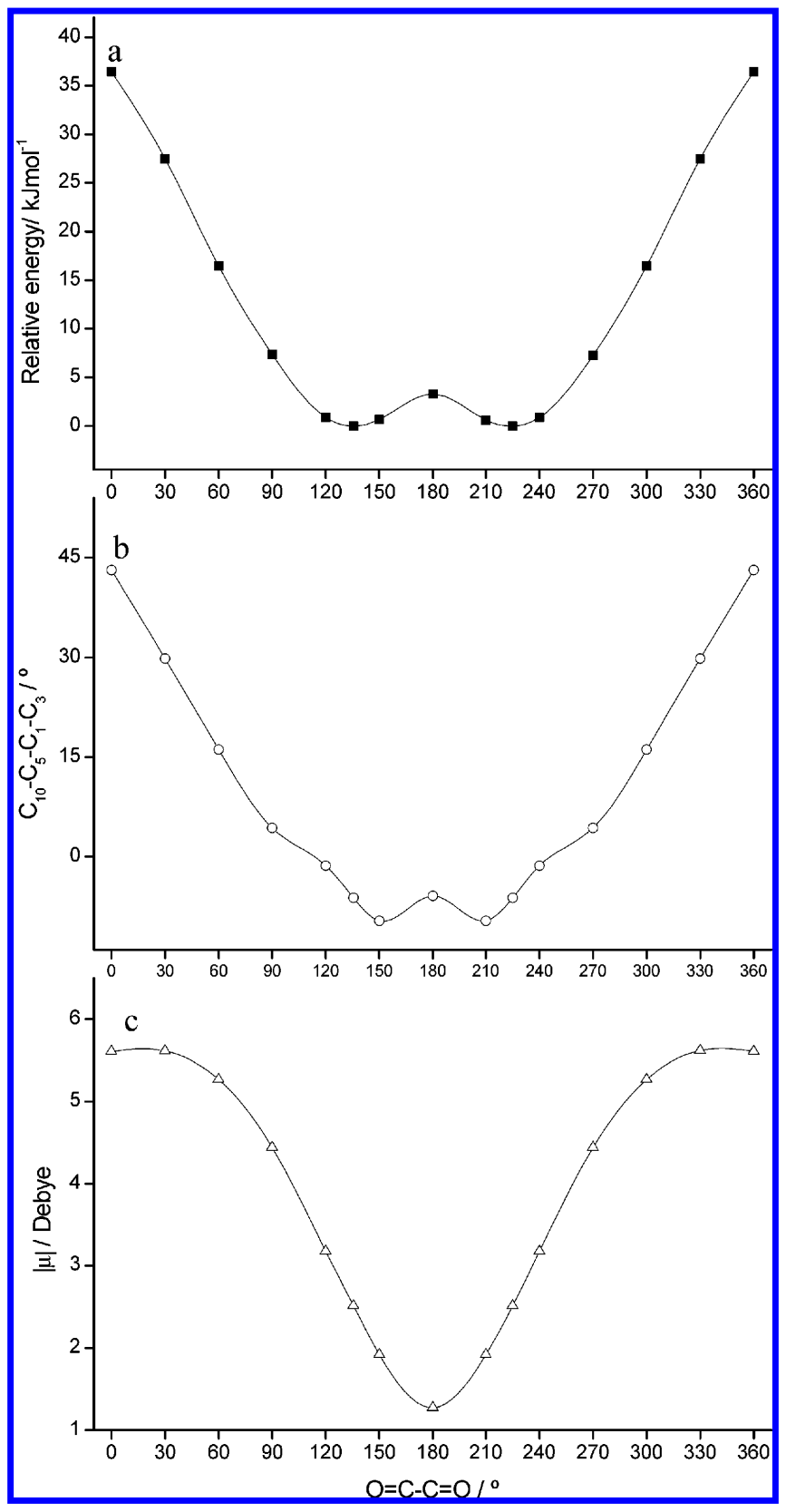

Figure 2. a. DFT(B3LYP)/6-311++G(d,p) calculated potential energy profile for internal rotation around the central $\mathrm{C}-\mathrm{C}$ bond of PPD (-口-). b. $\mathrm{C}_{10}-\mathrm{C}_{5}-\mathrm{C}_{1}-\mathrm{C}_{3}$ (-O-) dihedral angle as a function of the $\mathrm{O}=\mathrm{C}-\mathrm{C}=\mathrm{O}$ dihedral angle. $\mathrm{c}$. DFT(B3LYP)/6-311G(d,p) calculated dipole moment as a function of the $\mathrm{O}=\mathrm{C}-\mathrm{C}=\mathrm{O}$ dihedral angle $(-\triangle-)$.

the central $\mathrm{C}-\mathrm{C}$ bond from the Boltzmann distribution (see Figure 3), the energy-weighted dihedral angle can be estimated from eq 1

$$
|\alpha|=\int_{-180^{\circ}}^{180^{\circ}}\left|\alpha_{0}\right| N\left(\alpha_{0}\right) \mathrm{d} \alpha_{0}
$$

where $\alpha_{0}$ is the $\mathrm{O}=\mathrm{C}-\mathrm{C}=\mathrm{O}$ dihedral angle $\left(\alpha_{0} \in\left[-180^{\circ}\right.\right.$, $\left.180^{\circ}\right]$ ) and $N\left(\alpha_{0}\right)$ is the fractional population of molecules with the $\mathrm{O}=\mathrm{C}-\mathrm{C}=\mathrm{O}$ dihedral equal to $\alpha_{0}$, which is given by

$$
\left(\alpha_{0}\right)=\frac{\frac{-E\left(\alpha_{0}\right)}{R T}}{\int_{-180^{\circ}}^{180^{\circ}-E\left(\alpha_{0}\right)} \frac{-R T}{R T} \alpha_{0}}
$$

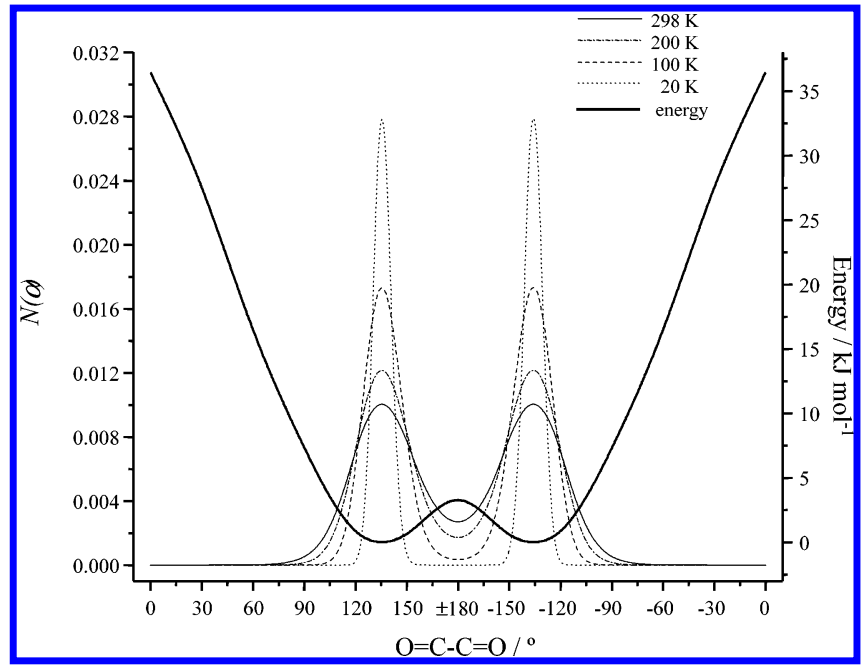

Figure 3. DFT(B3LYP)/6-311++G(d,p) calculated potential energy profile for internal rotation around the central $\mathrm{C}-\mathrm{C}$ bond of PPD (bold solid line) and energy-weighted fractional conformational populations (estimated accordingly to the Boltzmann distribution), for $T=20 \mathrm{~K}$ (‥) (temperature of the substrate), and $298 \mathrm{~K}$ (light solid) (nozzle

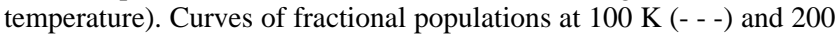
$\mathrm{K}$ (.-.-.) are also shown, for comparison.

Numerical integration of eq 1 , using the relative energies calculated at the DFT(B3LYP)/6-311++G(d,p) level of theory, gives an estimation of the energy-averaged $\mathrm{O}=\mathrm{C}-\mathrm{C}=\mathrm{O}$ dihedral angle at $298 \mathrm{~K}$ (the nozzle temperature used in this study) of $137.6^{\circ}$, being slightly larger than the equilibrium angle $\left(135.6^{\circ}\right)$. A slight modification of eq 1 enables determination of the energy-weighted average deviations of the $\mathrm{O}=\mathrm{C}-\mathrm{C}=\mathrm{O}$ dihedral angle from equilibrium in both $\mathrm{O}=\mathrm{C}-\mathrm{C}=\mathrm{O}$ increasing and decreasing directions (to do this it is only necessary to change the integration interval to the appropriated ones, regions of positive and negative deviations of the dihedral from the equilibrium, and renormalize the weighting function appropriately). The deviations (smaller dihedral:larger dihedral; skewness) change from $\left(23.0^{\circ}: 29.6^{\circ} ; 6.52^{\circ}\right)$, for room temperature to $\left(1.57^{\circ}: 1.60^{\circ} ; 0.03^{\circ}\right)$ at $20 \mathrm{~K}$. One could also use the classical turning points of the various vibrational energy levels as a measure of the deviations from the calculated torsion angle, reaching essentially the same general conclusions. At $20 \mathrm{~K}$, mainly the vibrational ground state, lying ca. $0.2 \mathrm{~kJ} \mathrm{~mol}^{-1}$ above the potential energy minimum is populated. At $298 \mathrm{~K}$, RT is $2.5 \mathrm{~kJ} \mathrm{~mol}^{-1}$, and population of the vibrational levels with energies comparable to this value becomes significantly probable. These results were found to be relevant for the interpretation of the experimental results obtained in this study, as it will be discussed in detail further below.

Figure 2 also displays the variation of the $\mathrm{C}_{10}-\mathrm{C}_{5}-\mathrm{C}_{1}-\mathrm{C}_{3}$ dihedral angle, which describes the relative geometry of the phenyl group relative to the vicinal carbonyl group $\left(\mathrm{C}_{1}=\mathrm{O}_{2}\right)$, with the rotation around the central $\mathrm{C}-\mathrm{C}$ bond [Figure $2 \mathrm{~b}$ ]. It is clear from this figure that around the minimum energy conformation the phenyl group tends to stay in the plane of the $\mathrm{C}_{1}=\mathrm{O}_{2}$ bond, whereas for the sterically more hindered conformations close to the cis configuration, the phenyl group rotates considerably from that plane (ca. $43^{\circ}$ for the maximum energy conformation), to minimize strain.

The dipole moment also depends on the value of the $\mathrm{O}=\mathrm{C}-\mathrm{C}=\mathrm{O}$ dihedral angle, as shown in Figure $2 \mathrm{c}$. The lowest dipole moment occurs for the trans conformation $(1.3 \mathrm{D})$ and attains its maximum value $(5.6 \mathrm{D})$ for a structure close to the cis conformation. 


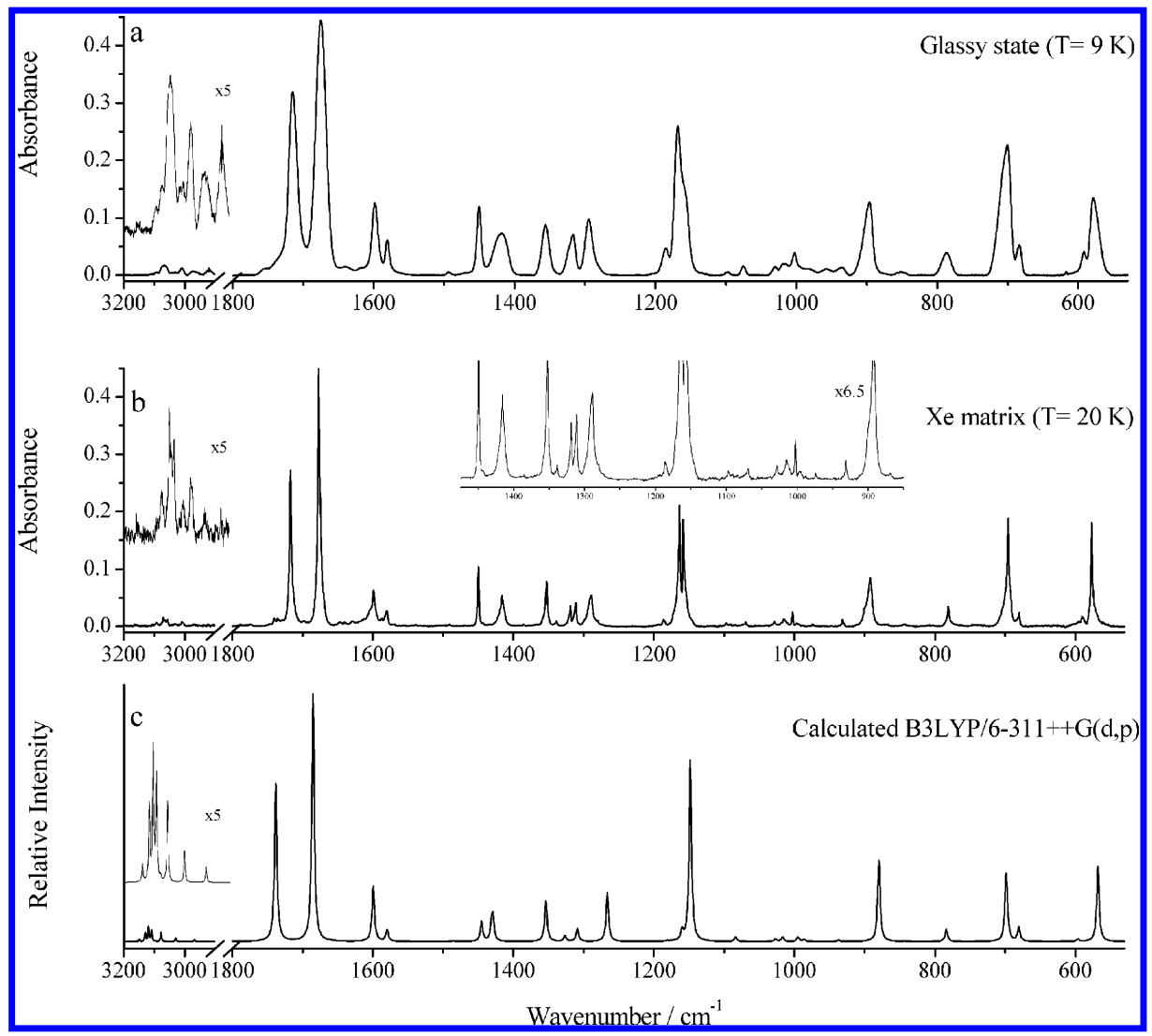

Figure 4. Infrared spectra of PPD in (a) the glassy state at $9 \mathrm{~K}$; (b) a xenon matrix (substrate temperature $=20 \mathrm{~K}$; nozzle temperature $=298 \mathrm{~K}$ ); (c) DFT(B3LYP)/6-311++G(d,p) calculated spectrum for the minimum energy conformation. Calculated spectra were simulated using Lorentzian functions centered at the calculated (scaled) frequency and with bandwidth at half-height equal to $5 \mathrm{~cm}^{-1}$.

Assignment of the Vibrational Spectra and Annealing Experiments for the Matrix-Isolated Compound. PPD molecule has 51 fundamental vibrations, all of them active in the infrared. A definition of the internal coordinates adopted in the vibrational analysis is provided in Table S2 (Supporting Information). The calculated wavenumbers, infrared intensities, and potential energy distribution resulting from normal-mode analysis, carried out for the minimum energy conformation, are presented in Table S3 (Supporting Information). Figure 4 displays the spectrum of PPD isolated in solid xenon at $20 \mathrm{~K}$, together with that of the neat compound in the solid amorphous state at $9 \mathrm{~K}$ and the calculated spectrum. Table 1 presents the assignments for the fundamental bands. The assignment of the spectra is straightforward and strongly aided by the excellent agreement between the experimental and the calculated spectra. The only point deserving here further comments refers to the splitting observed in some of the bands in the experimental spectra of matrix-isolated and amorphous PPD, which can be attributed to Fermi resonance (FR) interactions. Hence, the doublets observed at 1353.8/1352.4 $\left(\delta \mathrm{CH}_{3} \mathrm{~s}\right), 1292.5 / 1288.7$ $\left[v\left(\mathrm{C}-\mathrm{C}_{\alpha}\right)\right], 1163.4 / 1158.0\left(\gamma \mathrm{CH}_{3}\right.$; in the neat amorphous state the doublet due to this mode is observed at $\left.1168.4 / 1159.8 \mathrm{~cm}^{-1}\right)$, $1097.3 / 1069.8$ [ $v(\mathrm{C}-\mathrm{C}$ ring 6$)$; in the amorphous state: $1098.0 /$ $\left.1075.7 \mathrm{~cm}^{-1}\right]$, and $899.1 / 891.8\left[v\left(\mathrm{C}-\mathrm{CH}_{3}\right)\right] \mathrm{cm}^{-1}$ result, with all probability, from FR interactions of the indicated fundamental vibrations with the following overtones or combination tones: $2 \tau($ ring 1$), \tau($ ring 1$)+\delta(\operatorname{ring} 2), 2 \delta\left(\mathrm{C}_{3}=\mathrm{O}\right), \tau(\operatorname{ring} 3)+\tau($ ring 1 ), and $2 \gamma$ (ring) (see also Table 1). On the other hand, the band splitting observed in the crystal-state spectrum is extensive (Figure S1; Supporting Information), but in this case, it shall be essentially attributed to crystal field effects.

Like in diacetyl and benzil, ${ }^{38,39}$ also in PPD the torsion around the intercarbonyl $\mathrm{C}-\mathrm{C}$ bond corresponds to a low frequency, large amplitude vibration. The calculated $\tau \mathrm{C}-\mathrm{C}$ torsional frequency in PPD is only $43.9 \mathrm{~cm}^{-1}$ (being slightly higher than the equivalent vibration in diacetyl and benzil, which were estimated as 32 and $26 \mathrm{~cm}^{-1}$, respectively $\left.{ }^{38,39}\right)$. Hence, in the gas phase, at $298 \mathrm{~K}$ (the nozzle temperature), it can be expected that a significant number of molecules exist in a conformation where the $\mathrm{O}=\mathrm{C}-\mathrm{C}=\mathrm{O}$ dihedral angle is significantly smaller or larger than its equilibrium value. Thus, the spectrum of the as-deposited matrix (substrate temperature: $20 \mathrm{~K}$ ) shall reflect the contribution from all conformations significantly populated in the gas phase prior to deposition. Taking into consideration the fractional population curve for $T=298 \mathrm{~K}$ shown in Figure 3 , it can be expected that conformations with a $\mathrm{O}=\mathrm{C}-\mathrm{C}-\mathrm{O}$ dihedral angle ranging from ca. $90^{\circ}$ to $180^{\circ}$ contribute to the observed spectra in a significant extent. Figure S2 (Supporting Information) shows the dependence of the calculated infrared spectra of $\mathrm{PPD}$ on the $\mathrm{O}=\mathrm{C}-\mathrm{C}=\mathrm{O}$ dihedral angle. It is clear from this figure that changing the dihedral angle within the 90$180^{\circ}$ range should not lead to substantial changes in the IR spectrum. Nevertheless, the spectral positions of several bands are predicted to change by several wavenumbers. Therefore, at least for the most intense bands, the frequencies should shift upon annealing of the matrix to higher temperatures, since this operation is expected to enable conformational relaxation toward the equilibrium conformational distribution characteristic of the matrix temperature. As mentioned before, around the minimumenergy-conformation, the potential energy grows faster changing the $\mathrm{O}=\mathrm{C}-\mathrm{C}=\mathrm{O}$ dihedral toward the cis conformation than in the direction of the trans conformation. This means that conformational relaxation shall produce a larger reduction in the number of molecules with the $\mathrm{O}=\mathrm{C}-\mathrm{C}=\mathrm{O}$ dihedral angle larger than the equilibrium value than in those with a smaller dihedral angle. Figure 5 presents the difference spectrum (matrix 
TABLE 1: Experimental and Calculated Vibrational Data, and Results of Normal Coordinate Analysis for 1-Phenyl-1,2-propanedione ${ }^{a}$

\begin{tabular}{|c|c|c|c|c|c|c|c|c|c|}
\hline \multirow{3}{*}{$\begin{array}{l}\text { approximate } \\
\text { description }\end{array}$} & \multicolumn{2}{|c|}{ calculated } & \multicolumn{6}{|c|}{ experimental } & \multirow[b]{3}{*}{$\mathrm{PED}^{c}$} \\
\hline & \multirow[b]{2}{*}{ wavenumber $^{b}$} & \multirow[b]{2}{*}{ intensity } & \multicolumn{2}{|c|}{ xenon matrix $(20 \mathrm{~K})$} & \multicolumn{2}{|c|}{ glass (9 K) } & \multicolumn{2}{|l|}{$\begin{array}{l}\text { crystal }(9 \mathrm{~K}) \text { after one } \\
\text { cycle heating-cooling }\end{array}$} & \\
\hline & & & wavenumber & intensity $^{d}$ & wavenumber & intensity & wavenumber & intensity & \\
\hline$v(\mathrm{C}-\mathrm{H}$ ring 2$)$ & 3149.3 & 1.7 & 3092.2 & $\mathrm{w}$ & $3107.8 / 3089.7$ & $\mathrm{w} / \mathrm{w}$ & 3090.6 & $\mathrm{w}$ & $S_{12}(31), S_{13}(32), S_{14}(14), S_{15}(16)$ \\
\hline$v(\mathrm{C}-\mathrm{H}$ ring 1$)$ & 3129.8 & 7.3 & 3070.2 & $\mathrm{w}$ & 1 & & & & $\mathrm{~S}_{12}(45), \mathrm{S}_{13}(39), \mathrm{S}_{15}(10)$ \\
\hline$v(\mathrm{C}-\mathrm{H}$ ring 3$)$ & 3118.8 & 12.8 & 3066.5 & $\mathrm{w}$ & 3066.9 & $\mathrm{w}$ & 3062.8 & $\mathrm{w}$ & $\mathrm{S}_{12}(24), \mathrm{S}_{14}(52), \mathrm{S}_{16}(18)$ \\
\hline$v(\mathrm{C}-\mathrm{H}$ ring 4$)$ & 3109.3 & 10.2 & 3057.3 & w & & & & & $\mathrm{S}_{13}(24), \mathrm{S}_{15}(72)$ \\
\hline$v(\mathrm{C}-\mathrm{H}$ ring 5$)$ & 3097.3 & 0.4 & n.o. & & 3041.2 & w & n.o. & & $\mathrm{S}_{16}(74), \mathrm{S}_{14}(25)$ \\
\hline$\nu \mathrm{CH}_{3}$ as & 3077.7 & 7.8 & 3030.7 & w & 3029.0 & w & 3031.9 & $\mathrm{w}$ & $\mathrm{S}_{36}(96)$ \\
\hline$v \mathrm{CH}_{3}$ as' & 3029.4 & 3.1 & 3009.4 & w & 3009.4 & $\mathrm{w}$ & 3000.7 & $\mathrm{w}$ & $\mathrm{S}_{37}(93)$ \\
\hline$v \mathrm{CH}_{3} \mathrm{~S}$ & 2967.8 & 1.5 & 2969.9 & $\mathrm{w}$ & 2969.0 & w & 2960.4 & $\mathrm{w}$ & $\mathrm{S}_{35}(92)$ \\
\hline$v(\mathrm{C} 3=\mathrm{O})$ & 1738.1 & 139.0 & 1716.9 & $\mathrm{~S}$ & 1714.8 & $\mathrm{~s}$ & 1713.4/ 1711.4/ 1700.5/ 1696.2 & S/S/S/S & $\mathrm{S}_{3}(91)$ \\
\hline$v(\mathrm{C} 1=\mathrm{O})$ & 1685.0 & 217.6 & 1677.0 & $\mathrm{~S}$ & 1674.8 & $\mathrm{~s}$ & $1669.4 / 1664.2$ & $\mathrm{sh} / \mathrm{S}$ & $\mathrm{S}_{2}(90)$ \\
\hline$v(\mathrm{C}-\mathrm{C}$ ring 2$)$ & 1599.3 & 49.9 & 1598.9 & $\mathrm{~m}$ & 1598.2 & $\mathrm{~m}$ & $1594.3 / 1602.0$ & $\mathrm{~m} / \mathrm{m}$ & $S_{7}(65), S_{19}(10), S_{28}(21)$ \\
\hline$v(\mathrm{C}-\mathrm{C}$ ring 4$)$ & 1579.6 & 10.4 & 1580.1 & $\mathrm{w}$ & 1580.7 & $\mathrm{~m}$ & 1580.4 & $\mathrm{~m}$ & $\mathrm{~S}_{9}(66), \mathrm{S}_{27}(18)$ \\
\hline$\delta(\mathrm{C}-\mathrm{H}$ ring 2$)$ & 1486.1 & 0.6 & n.o. & & 1493.9 & w & 1493.7 & $\mathrm{~m}$ & $\mathrm{~S}_{10}(32), \mathrm{S}_{26}(63)$ \\
\hline$\delta(\mathrm{C}-\mathrm{H}$ ring 3$)$ & 1445.0 & 17.6 & 1449.5 & $\mathrm{~m}$ & 1450.3 & $\mathrm{~m}$ & 1450.3 & $\mathrm{~m}$ & $S_{11}(36), S_{25}(19), S_{27}(28), S_{29}(10)$ \\
\hline$\delta \mathrm{CH}_{3} \mathrm{as}$ & 1431.0 & 11.9 & 1416.0 & $\mathrm{~m}$ & 1418.7 & $\mathrm{~m}$ & $1428.5 / 1423.8$ & $\mathrm{~m} / \mathrm{m}$ & $\mathrm{S}_{39}(41), \mathrm{S}_{40}(49)$ \\
\hline$\delta \mathrm{CH}_{3} \mathrm{as}$ & 1429.0 & 20.1 & 1413.4 & sh & 1418.7 & $\mathrm{~m}$ & $1418.3 / 1410.8$ & $\mathrm{~m} / \mathrm{m}$ & $S_{39}(49), S_{40}(43)$ \\
\hline$\delta \mathrm{CH}_{3} \mathrm{~S}$ & 1353.6 & 37.4 & $1353.8 / 1352.4$ & $\mathrm{sh} / \mathrm{m}$ & 1356.0 & $\mathrm{~m}$ & $1366.7 / 1354.7 / 1353.0$ & $\mathrm{w} / \mathrm{sh} / \mathrm{S}$ & $\mathrm{S}_{38}(89)$ \\
\hline$\delta(\mathrm{C}-\mathrm{H}$ ring 1$)$ & 1326.4 & 5.0 & 1318.6 & w & 1324.6 & sh & $1329.2 / 1324.7$ & $\mathrm{~m} / \mathrm{m}$ & $\mathrm{S}_{8}(18), \mathrm{S}_{11}(11), \mathrm{S}_{25}(57)$ \\
\hline$v(\mathrm{C}-\mathrm{C}$ ring 3$)$ & 1308.7 & 11.2 & 1311.0 & $\mathrm{w}$ & 1316.9 & $\mathrm{~m}$ & 1320.3 & $\mathrm{~S}$ & $\mathrm{~S}_{8}(67), \mathrm{S}_{25}(20)$ \\
\hline$v\left(\mathrm{C}-\mathrm{C}_{\alpha}\right)$ & 1266.2 & 43.5 & $1292.5 / 1288.7$ & $\mathrm{sh} / \mathrm{m}$ & 1294.6 & $\mathrm{~m}$ & $1299.4 / 1295.8 / 1286.9$ & $\mathrm{~S} / \mathrm{S} / \mathrm{S}$ & $\mathrm{S}_{1}(18), \mathrm{S}_{4}(28)$ \\
\hline$\delta(\mathrm{C}-\mathrm{H}$ ring 4$)$ & 1181.1 & 0.4 & 1186.4 & w & 1184.9 & $\mathrm{~m}$ & $1192.4 / 1190.0$ & $\mathrm{~S} / \mathrm{S}$ & $\mathrm{S}_{7}(23), \mathrm{S}_{28}(67)$ \\
\hline$\delta(\mathrm{C}-\mathrm{H}$ ring 5$)$ & 1159.8 & 8.7 & 1171.4 & $\mathrm{w}$ & n.o. & & n.o. & & $\mathrm{S}_{8}(10), \mathrm{S}_{27}(12), \mathrm{S}_{29}(64)$ \\
\hline$\gamma \mathrm{CH}_{3}$ & 1148.1 & 159.5 & $1163.4 / 1158.0$ & $\mathrm{~S} / \mathrm{S}$ & $1168.4 / 1159.8$ & $\mathrm{~S} / \mathrm{sh}$ & 1176.4/ 1164.6/ 1157.2/ 1136.3 & $\mathrm{~S} / \mathrm{S} / \mathrm{S} / \mathrm{m}$ & $\mathrm{S}_{4}(12), \mathrm{S}_{5}(13), \mathrm{S}_{41}(17), \mathrm{S}_{47}(18)$ \\
\hline$v(\mathrm{C}-\mathrm{C}$ ring 6$)$ & 1083.8 & 3.9 & $1097.3 / 1069.8$ & $\mathrm{w} / \mathrm{w}$ & $1098.0 / 1075.7$ & $\mathrm{w} / \mathrm{w}$ & $1105.5 / 1078.5$ & $\mathrm{w} / \mathrm{m}$ & $\mathrm{S}_{11}(51), \mathrm{S}_{27}(32)$ \\
\hline$v(\mathrm{C}-\mathrm{C}$ ring 5$)$ & 1027.1 & 2.2 & 1028.0 & w & 1030.1 & $\mathrm{w}$ & $1032.1 / 1029.9$ & $\mathrm{w} / \mathrm{w}$ & $\mathrm{S}_{10}(53), \mathrm{S}_{26}(23)$ \\
\hline$\gamma \mathrm{CH}_{3}$ & 1016.9 & 3.9 & 1015.0 & $\mathrm{w}$ & 1019.3 & $\mathrm{w}$ & $1024.3 / 1022.8 / 1012.3 / 1009.3$ & $\mathrm{~m} / \mathrm{m} / \mathrm{m} / \mathrm{m}$ & $\mathrm{S}_{42}(51), \mathrm{S}_{45}(20)$ \\
\hline$\delta$ (ring 1) & 995.1 & 3.9 & 1002.5 & $\mathrm{w}$ & 1002.7 & w & 1000.1 & $\mathrm{~m}$ & $\mathrm{~S}_{6}(22), \mathrm{S}_{17}(62)$ \\
\hline$\gamma(\mathrm{C}-\mathrm{H}$ ring 5$)$ & 991.4 & 0.2 & 996.0 & $\mathrm{w}$ & 996.1 & $\mathrm{w}$ & 995.7 & $\mathrm{~m}$ & $\mathrm{~S}_{6}(13), \mathrm{S}_{20}(19), \mathrm{S}_{34}(46)$ \\
\hline$v(\mathrm{C}-\mathrm{C}$ ring 1$)$ & 986.0 & 1.6 & 988.1 & $\mathrm{w}$ & 981.2 & w & 989.8 & $\mathrm{~m}$ & $\mathrm{~S}_{6}(16), \mathrm{S}_{34}(11), \mathrm{S}_{41}(29)$ \\
\hline$\gamma(\mathrm{C}-\mathrm{H}$ ring 4$)$ & 978.4 & 0.3 & 974.0 & w & 981.2 & $\mathrm{w}$ & 987.8 & $\mathrm{~m}$ & $\mathrm{~S}_{22}(23), \mathrm{S}_{33}(65)$ \\
\hline$\gamma(\mathrm{C}-\mathrm{H}$ ring 3$)$ & 936.7 & 1.2 & 931.4 & $\mathrm{w}$ & 935.5 & w & $949.7 / 944.3$ & $\mathrm{~m} / \mathrm{m}$ & $\mathrm{S}_{21}(11), \mathrm{S}_{32}(71)$ \\
\hline$v(\mathrm{C}-\mathrm{CH} 3)$ & 879.7 & 73.0 & $899.1 / 891.8$ & $\mathrm{sh} / \mathrm{S}$ & 896.6 & $\mathrm{~s}$ & $914.7 / 907.9$ & $\mathrm{~S} / \mathrm{S}$ & $\mathrm{S}_{5}(38), \mathrm{S}_{6}(10), \mathrm{S}_{46}(17)$ \\
\hline$\gamma(\mathrm{C}-\mathrm{H}$ ring 2$)$ & 843.6 & 0.4 & 843.1 & $\mathrm{w}$ & 849.1 & w & 853.0 & $\mathrm{w}$ & $\mathrm{S}_{31}(99)$ \\
\hline$\gamma(\mathrm{C}-\mathrm{H}$ ring 1$)$ & 783.9 & 10.9 & 780.9 & $\mathrm{~m}$ & 786.8 & $\mathrm{~m}$ & 801.2 & $\mathrm{~S}$ & $\mathrm{~S}_{24}(23), \mathrm{S}_{30}(33), \mathrm{S}_{44}(19)$ \\
\hline$\gamma\left(C_{1}=0\right)$ & 698.7 & 50.9 & 696.0 & $\mathrm{~S}$ & 708.0 & $\mathrm{~S}$ & $722.0 / 717.5$ & $\mathrm{~S} / \mathrm{S}$ & $\mathrm{S}_{30}(41), \mathrm{S}_{44}(26)$ \\
\hline$v(\mathrm{C}-\mathrm{C})$ & 697.6 & 14.3 & 692.8 & sh & 700.7 & $\mathrm{~s}$ & $712.9 / 710.5$ & S/ S & $S_{1}(11), S_{4}(10), S_{19}(36)$ \\
\hline$\tau($ ring 1$)$ & 680.6 & 12.8 & 679.9 & $\mathrm{~m}$ & 684.2 & $\mathrm{~m}$ & $689.3 / 688.3$ & $\mathrm{~S}$ & $\mathrm{~S}_{20}(54), \mathrm{S}_{34}(24)$ \\
\hline$\delta$ (ring 2) & 617.0 & 0.1 & 617.2 & w & 617.4 & w & $618.4 / 614.6$ & $\mathrm{~m} / \mathrm{m}$ & $\mathrm{S}_{18}(86)$ \\
\hline$\gamma\left(\mathrm{C}_{3}=\mathrm{O}\right)$ & 596.5 & 1.7 & 589.4 & $\mathrm{~m}$ & 592.0 & $\mathrm{~m}$ & 584.8 & $\mathrm{~m}$ & $\mathrm{~S}_{42}(13), \mathrm{S}_{45}(21), \mathrm{S}_{48}(32), \mathrm{S}_{49}(11)$ \\
\hline$\delta\left(\mathrm{C}_{3}=\mathrm{O}\right)$ & 568.0 & 66.0 & 576.6 & $\mathrm{~S}$ & 578.6 & $\mathrm{~s}$ & $569.7 / 566.3$ & $\mathrm{~S} / \mathrm{S}$ & $\mathrm{S}_{41}(10), \mathrm{S}_{46}(26), \mathrm{S}_{47}(56)$ \\
\hline$\gamma($ ring $)$ & 450.2 & 3.5 & 450.6 & $\mathrm{w}$ & 448.6 & $\mathrm{w}$ & 479.7 & $\mathrm{w}$ & $S_{21}(23), S_{24}(36)$ \\
\hline$\delta$ (ring 3 ) & 416.4 & 0.5 & n.i. & n.i. & n.i. & n.i. & n.i. & & $\mathrm{S}_{4}(18), \mathrm{S}_{19}(23), \mathrm{S}_{46}(17)$ \\
\hline$\tau$ (ring 3 ) & 400.0 & 0.0 & n.i. & n.i. & n.i. & n.i. & n.i. & & $\mathrm{S}_{22}(70), \mathrm{S}_{33}(25)$ \\
\hline$\delta\left(\mathrm{C}_{1}=\mathrm{O}\right)$ & 345.5 & 5.4 & n.i. & n.i. & n.i. & n.i. & n.i. & & $S_{1}(20), S_{45}(16), S_{46}(29), S_{47}(35)$ \\
\hline$\omega$ (ring) & 280.3 & 2.3 & n.i. & n.i. & n.i. & n.i. & n.i. & & $\mathrm{S}_{1}(10), \mathrm{S}_{4}(10), \mathrm{S}_{23}(25), \mathrm{S}_{47}(13), \mathrm{S}_{48}(19)$ \\
\hline$\delta\left(\mathrm{CC}_{3} \mathrm{C}\right)$ & 258.3 & 17.0 & n.i. & n.i. & n.i. & n.i. & n.i. & & $\mathrm{S}_{23}(16), \mathrm{S}_{44}(10), \mathrm{S}_{49}(81)$ \\
\hline$\delta\left(\mathrm{CC}_{1} \mathrm{C}\right)$ & 159.9 & 1.9 & n.i. & n.i. & n.i. & n.i. & n.i. & & $\mathrm{S}_{23}(23), \mathrm{S}_{48}(54)$ \\
\hline$\tau($ ring 2$)$ & 137.8 & 1.1 & n.i. & n.i. & n.i. & n.i. & n.i. & & $\mathrm{S}_{21}(31), \mathrm{S}_{24}(24), \mathrm{S}_{44}(10)$ \\
\hline$\tau \mathrm{CH}_{3}$ & 118.2 & 0.1 & n.i. & n.i. & n.i. & n.i. & n.i. & & $\mathrm{S}_{43}(95)$ \\
\hline$\tau(\mathrm{C}-\mathrm{C})$ & 43.9 & 4.8 & n.i. & n.i. & n.i. & n.i. & n.i. & & $\mathrm{S}_{50}(54), \mathrm{S}_{51}(37)$ \\
\hline$\tau\left(\mathrm{C}-\mathrm{C}_{\alpha}\right)$ & 36.7 & 3.6 & n.i. & n.i. & n.i. & n.i. & n.i. & & $\mathrm{S}_{50}(40), \mathrm{S}_{51}(55)$ \\
\hline
\end{tabular}

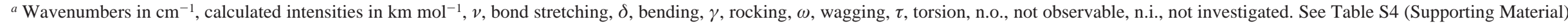

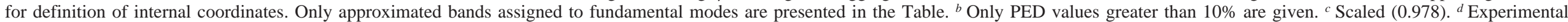
intensities are presented in qualitative terms: $\mathrm{S}=$ strong, $\mathrm{m}=$ medium; $\mathrm{w}=$ weak 


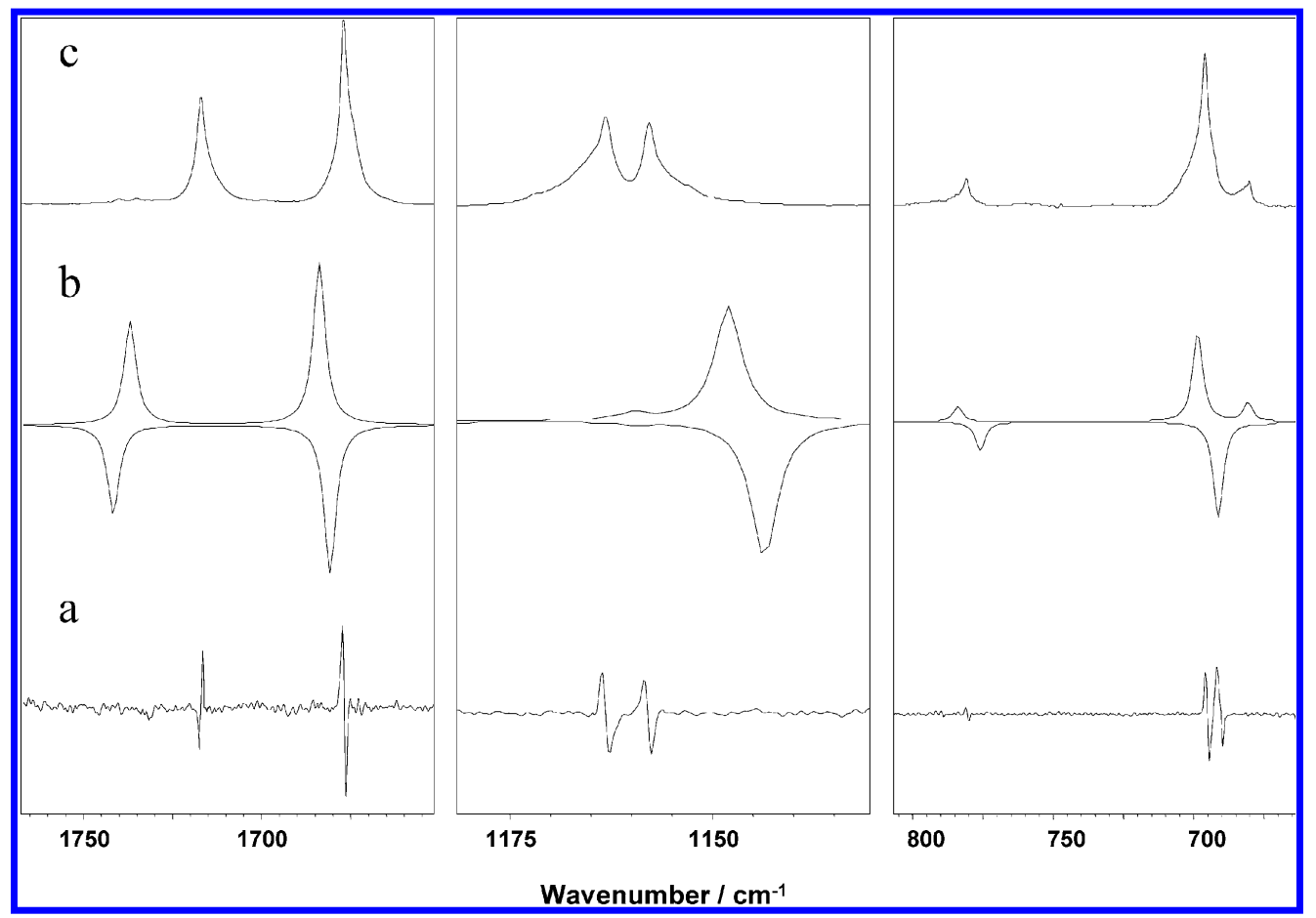

Figure 5. Selected spectral regions of the infrared spectra of PPD: (a) difference spectrum: xenon matrix annealed to $45 \mathrm{~K}$ minus as-deposited matrix; (b) DFT(B3LYP)/6-311++G(d,p) calculated spectra for the minimum energy conformation (up) and trans conformation (down); (c) asdeposited infrared spectrum in xenon matrix (substrate temperature $=20 \mathrm{~K}$; nozzle temperature $=298 \mathrm{~K}$ ). In the difference spectrum shown the broad low intensity bands due to traces of aggregated species were subtracted and the baseline was corrected. The $1750-1650 \mathrm{~cm}^{-1} \mathrm{spectral} \mathrm{region}$ refers to the $v\left(\mathrm{C}_{3}=\mathrm{O}\right)$ and $v\left(\mathrm{C}_{1}=\mathrm{O}\right)$ absorptions; in the $1175-1100 \mathrm{~cm}^{-1}$ spectral region only the doublet of Fermi ascribed to the $\gamma \mathrm{CH}_{3}$ mode gives rise to observable difference features; in the $800-650 \mathrm{~cm}^{-1}$ region, the difference bands are due to $\gamma(\mathrm{C}-\mathrm{H}$ ring 1$)\left(\right.$ around $\left.780 \mathrm{~cm}^{-1}\right)$ and $\gamma\left(\mathrm{C}_{1}=\mathrm{O}\right)$ and $\nu(\mathrm{C}-\mathrm{C})$ (around $\left.690 \mathrm{~cm}^{-1}\right)$, the last two bands are overlapped in the reference spectrum (trace c) and in the calculated spectra (the small band in the calculated spectrum of the minimum energy conformation of PPD appearing at $680.6 \mathrm{~cm}^{-1}$ corresponds to the $\tau$ (ring 1) mode and does not give rise to any observable feature in the difference spectrum). Calculated spectra were simulated using Lorentzian functions centered at the calculated (scaled) frequency and with bandwidth at half-height equal to $5 \mathrm{~cm}^{-1}$.

annealed to $45 \mathrm{~K}$ minus as-deposited matrix), in the regions where PPD exhibits the most intense bands. In this figure, the calculated spectra for the minimum energy (bands pointing up) and trans (bands pointing down) conformations are also shown for comparison, as well as the spectrum of the as-deposited matrix (for reference). It is clear from this figure that the spectral changes correlate well with the expected preferential reduction of the amount of molecules with $\mathrm{O}=\mathrm{C}-\mathrm{C}=\mathrm{O}$ dihedral angles larger than the equilibrium value; that is, the observed frequency shifts follow the same trend as upon changing from the trans to the equilibrium conformation.

By analogy to the case of benzil, ${ }^{39}$ it can even be presumed that the minimum-energy-conformation of a matrix-isolated PPD molecule should correspond to a $\mathrm{O}=\mathrm{C}-\mathrm{C}=\mathrm{O}$ dihedral somewhat smaller than for the molecule in the gas-phase, since the torsional potential can be changed as a result of interactions with the matrix media, favoring more polar conformations, which correspond to those with smaller $\mathrm{O}=\mathrm{C}-\mathrm{C}=\mathrm{O}$ dihedral angles [see Figure 2c]. Stabilization of more polar structures in matrixes, when compared with gas phase, is a common phenomenon, previously reported for various molecules with appreciable conformational flexibility. ${ }^{39,72,73}$ It shall also be pointed out that annealing of the matrix to temperatures higher than $45 \mathrm{~K}$ was attempted in order to make the changes due to conformational relaxation more evident and enable also an analysis of other spectral regions (where PPD gives rise to less intense bands). However, it was found that the compound quickly aggregates at temperatures higher than ca. $45 \mathrm{~K}$, as reflected in the appearance in the spectrum of characteristic bands due to these species (at similar frequencies to those observed in the spectrum of the neat low-temperature amorphous solid). The appearance of the bands due to aggregates precludes clear identification of spectral changes due to pure conformational relaxation.

UV Induced Decomposition in Xenon Matrix. Spectroscopic changes resulting from UV $(\lambda>235 \mathrm{~nm})$ irradiation of the matrix-isolated PPD are shown in Figure 6. Selected spectral regions are presented in an expanded form in Figure S3 (Supporting Information). It is clear from these spectra that upon irradiation PPD decarbonylates, yielding carbon monoxide (CO) and acetophenone (1-phenyl-2-propanone; $\mathrm{C}_{6} \mathrm{H}_{5} \mathrm{COCH}_{3}$ )

$$
\mathrm{C}_{6} \mathrm{H}_{5} \mathrm{COCOCH}_{3} \rightarrow \mathrm{CO}+\mathrm{C}_{6} \mathrm{H}_{5} \mathrm{COCH}_{3}
$$

Because acetophenone has only one conformer (Figure 7), its identification on the basis of the spectrum recorded after irradiation of the matrix was an easy task. The assignment of the IR bands due to this photoproduct (presented in Table 2) was made at leisure [see also Table S4 (Supporting Information), for definition of symmetry coordinates].

The IR spectrum of $\mathrm{CO}$ isolated in xenon matrix at $20 \mathrm{~K}$ has been previously studied by Lee. ${ }^{74}$ The spectrum of the isolated CO monomer shows essentially a single band centered at 2133.1 $\mathrm{cm}^{-1}$, associated with molecules with energies less than the rotational energy barrier (ca. $35 \mathrm{~cm}^{-174}$ ). This band shows broad wings due to the fraction of molecules undergoing nearly free rotation in the matrix cage. On the other hand, the spectrum resulting from PPD decomposition exhibits several bands in the $2130-2140 \mathrm{~cm}^{-1}$ spectral range, as shown in Figure 8 . The band of the $\mathrm{CO}$ isolated monomer is observed at the expected frequency $\left(2133.1 \mathrm{~cm}^{-1}\right)$, also exhibiting the expected broad wing for low frequencies due to freely rotating molecules. The 


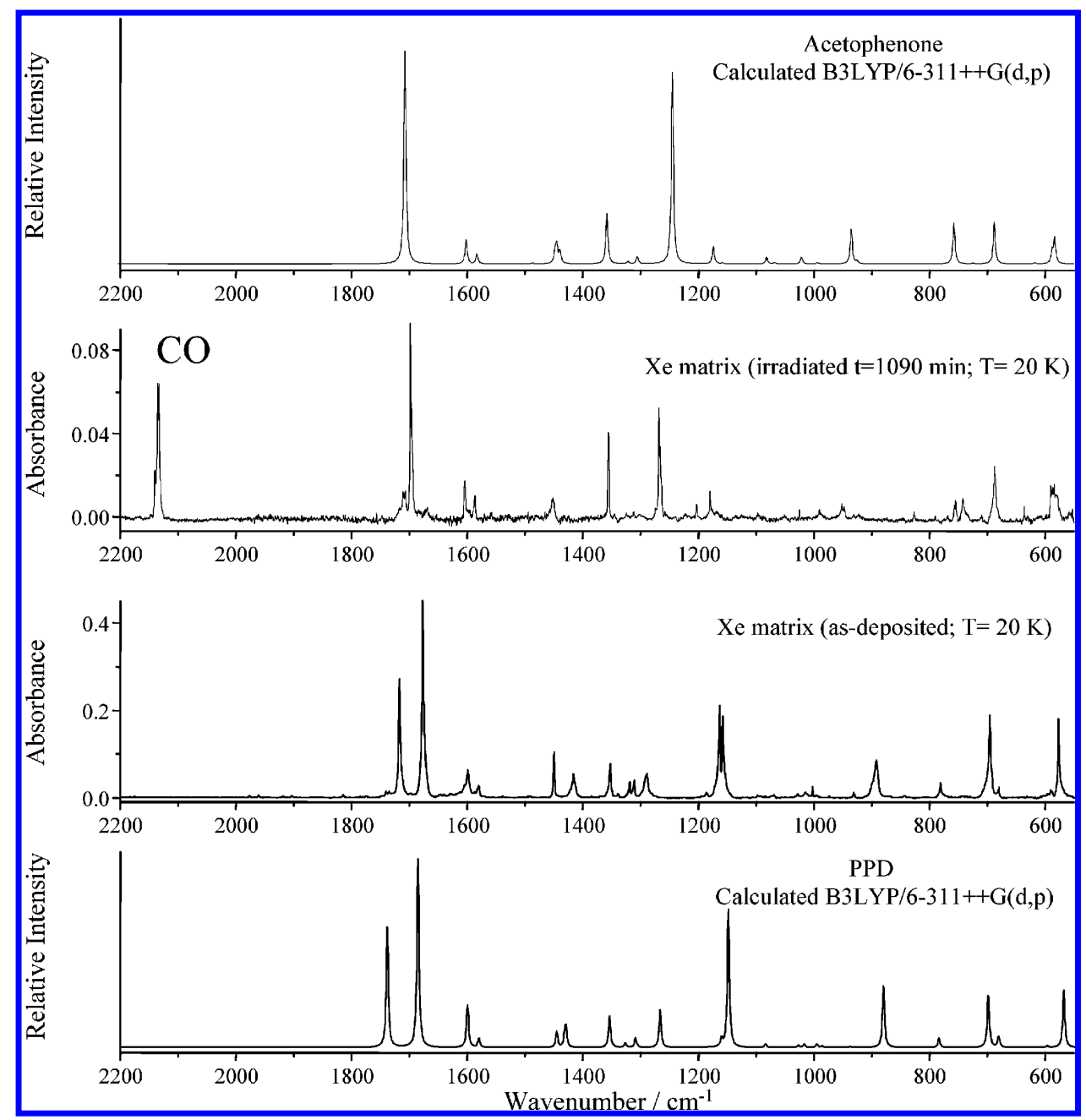

Figure 6. Infrared spectra of the as-deposited xenon matrix of PPD and of the UV $(\lambda>235 \mathrm{~nm})$ irradiated matrix (after 1090 min of irradiation). These spectra are compared with the DFT(B3LYP)/6-311++G(d,p) calculated spectra of acetophenone (top spectrum) and PPD (bottom spectrum). The calculated bands were simulated using Lorentzian functions centered at the scaled frequency and with bandwidth at half-height equal to 5 $\mathrm{cm}^{-1}$.

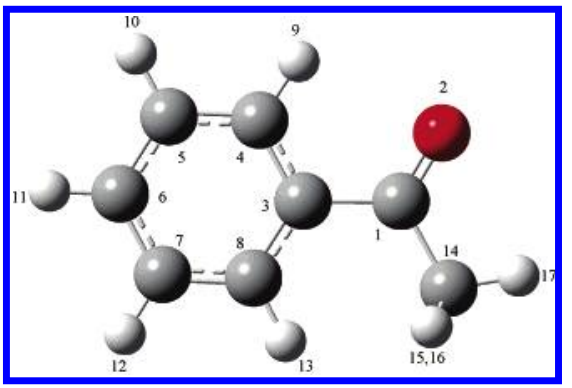

Figure 7. Minimum energy conformation of acetophenone $\left(C_{s}\right.$ symmetry) with atom numbering.

high-frequency component associated with free rotating $\mathrm{CO}$ molecules cannot be observed since it is superimposed with the intense band at $2135.2 \mathrm{~cm}^{-1}$, which shall be assigned to $\mathrm{CO}$ molecules complexed with acetophenone. Taking into consideration previous results for matrix-isolated complexes of $\mathrm{CO}$ with other species in xenon matrixes, ${ }^{75}$ it is probable that the complex formed between $\mathrm{CO}$ and acetophenone has a structure where the carbon atom is directed toward the acetophenone molecule. Finally, the less intense bands observed at ca. 2138 and $2140.0 \mathrm{~cm}^{-1}$ shall be ascribed to aggregates of $\mathrm{CO}$ and to the complex established between $\mathrm{CO}$ and traces of water present in the matrix as impurity. In the argon matrix, where the $\mathrm{CO}$ monomer absorbs at $2138.4 \mathrm{~cm}^{-1}, 75,76$ the $\mathrm{H}_{2} \mathrm{O} / \mathrm{CO}$ complex was found to give rise to a band at $2148 \mathrm{~cm}^{-176}$ and the $\mathrm{CO}$ aggregates were found to give rise to a broader band with maximum at $2139.9 \mathrm{~cm}^{-1},{ }^{76}$ thus correlating well with the bands now observed in xenon.

From the analysis of the profile of the band due to the $\mathrm{CO}$ stretching vibration, which appeared upon UV $(\lambda>235 \mathrm{~nm})$ irradiation of matrix-isolated PPD, the following conclusion can be extracted: photogenerated $\mathrm{CO}$ molecules can both stay in the primary matrix cage and form a complex with acetophenone or diffuse through the matrix and then appear as isolated monomer (with a fraction of molecules giving rise to $\mathrm{CO}$ aggregates and the $\mathrm{H}_{2} \mathrm{O} / \mathrm{CO}$ complex).

The mechanism of decarbonylation cannot be firmly stated from the spectroscopic results, since no intermediates could be detected. However, since the cage confinement substantially reduces the number of possible reactions, the following sequence of processes appears to be the most probable: in a similar way as in the case of the Norrish type I photoprocess in acetone, ${ }^{77,78}$ upon irradiation, PPD is excited to an excited singlet state and converted, by intersystem crossing, into the $\mathrm{T}_{1}$ triplet state, in which the homolytic cleavage of the intercarbonyl $\mathrm{C}-\mathrm{C}$ bond occurs. The primary photoproducts are then the benzoyl and acetyl radicals. The acetyl radical is considerably less stable than the benzoyl radical ${ }^{79}$ and is known to decompose easily into $\mathrm{CH}_{3}$ and $\mathrm{CO}$ upon irradiation at $\lambda>235 \mathrm{~nm} .{ }^{80-86}$ Then, before the benzoyl radical has time to decompose to $\mathrm{CO}+$ phenyl radical, the acetyl radical decomposition shall take place 
TABLE 2: Experimental and Calculated Vibrational Data, and Results of Normal Coordinate Analysis for Acetophenone ${ }^{a}$

\begin{tabular}{|c|c|c|c|c|c|c|}
\hline \multirow{3}{*}{$\begin{array}{l}\text { approximate } \\
\text { description }\end{array}$} & & \multirow{2}{*}{\multicolumn{2}{|c|}{ calculated }} & \multicolumn{2}{|c|}{ experimental } & \multirow[b]{3}{*}{$\mathrm{PED}^{b}$} \\
\hline & & & & \multirow{2}{*}{$\begin{array}{l}\text { irradiated xenon matrix } \\
\text { wavenumber }(20 \mathrm{~K})\end{array}$} & \multirow[b]{2}{*}{ intensity $^{d}$} & \\
\hline & & wavenumber $^{c}$ & intensity & & & \\
\hline$v \mathrm{C}-\mathrm{H}$ ring 1$)$ & $\mathrm{A}^{\prime}$ & 3129.7 & 6.1 & n.o. & n.o. & $S_{10}(54), S_{11}(26)$ \\
\hline$v(\mathrm{C}-\mathrm{H}$ ring 2$)$ & $\mathrm{A}^{\prime}$ & 3123.6 & 10.2 & n.o. & n.o. & $S_{11}(52), S_{10}(40)$ \\
\hline$v(\mathrm{C}-\mathrm{H}$ ring 3$)$ & $A^{\prime}$ & 3114.4 & 16.7 & n.o. & n.o. & $S_{12}(72), S_{14}(15)$ \\
\hline$v(\mathrm{C}-\mathrm{H}$ ring 4$)$ & $\mathrm{A}^{\prime}$ & 3105.2 & 7.3 & n.o. & n.o. & $\mathrm{S}_{13}(85), \mathrm{S}_{11}(13)$ \\
\hline$v(\mathrm{C}-\mathrm{H}$ ring 5$)$ & $\mathrm{A}^{\prime}$ & 3095.0 & 0.1 & n.o. & n.o. & $\mathrm{S}_{14}(82), \mathrm{S}_{12}(18)$ \\
\hline$\nu \mathrm{CH}_{3}$ as & $\mathrm{A}^{\prime}$ & 3073.9 & 11.7 & n.o. & n.o. & $\mathrm{S}_{34}(95)$ \\
\hline$\nu \mathrm{CH}_{3}$ as' & $A^{\prime \prime}$ & 3022.7 & 7.9 & n.o. & n.o. & $\mathrm{S}_{35}(100)$ \\
\hline$v \mathrm{CH}_{3} \mathrm{~S}$ & $\mathrm{~A}^{\prime}$ & 2966.5 & 2.9 & n.o. & n.o. & $\mathrm{S}_{33}(95)$ \\
\hline$v(\mathrm{C} 1=\mathrm{O})$ & $\mathrm{A}^{\prime}$ & 1707.6 & 214.7 & $1710.7 / 1706.6 / 1697.8$ & $\mathrm{w} / \mathrm{w} / \mathrm{S}$ & $\mathrm{S}_{1}(87)$ \\
\hline$v(\mathrm{C}-\mathrm{C}$ ring 2$)$ & $A^{\prime}$ & 1601.3 & 23.0 & 1599.1 & w & $S_{5}(66), S_{17}(10), S_{26}(21)$ \\
\hline$v(\mathrm{C}-\mathrm{C}$ ring 4$)$ & $\mathrm{A}^{\prime}$ & 1583.2 & 9.9 & $1589.9 / 1586.3 / 1579.8$ & $\mathrm{w} / \mathrm{w} / \mathrm{w}$ & $\mathrm{S}_{7}(67), \mathrm{S}_{25}(16)$ \\
\hline$\delta(\mathrm{C}-\mathrm{H}$ ring 2$)$ & $A^{\prime}$ & 1486.9 & 0.8 & 1482.3 & $\mathrm{w}$ & $\mathrm{S}_{24}(62), \mathrm{S}_{8}(33)$ \\
\hline$\delta \mathrm{CH}_{3}$ as & $A^{\prime \prime}$ & 1447.2 & 12.1 & 1453.3 & w & $\mathrm{S}_{38}(94)$ \\
\hline$\delta(\mathrm{C}-\mathrm{H}$ ring 3$)$ & $A^{\prime}$ & 1445.2 & 16.6 & 1451.7 & w & $S_{25}(29), S_{9}(36), S_{23}(19)$ \\
\hline$\delta \mathrm{CH}_{3}$ as & $\mathrm{A}^{\prime}$ & 1437.7 & 12.4 & 1432.1 & w & $\mathrm{S}_{37}(90)$ \\
\hline$\delta \mathrm{CH}_{3} \mathrm{~s}$ & $\mathrm{~A}^{\prime}$ & 1356.0 & 50.3 & 1355.7 & $\mathrm{~m}$ & $\mathrm{~S}_{36}(88)$ \\
\hline$\delta(\mathrm{C}-\mathrm{H}$ ring 1$)$ & $\mathrm{A}^{\prime}$ & 1321.5 & 1.9 & 1324.7 & w & $S_{23}(47), S_{6}(27), S_{9}(11), S_{27}(10)$ \\
\hline$v(\mathrm{C}-\mathrm{C}$ ring 3$)$ & $A^{\prime}$ & 1306.7 & 6.2 & 1312.2 & $\mathrm{w}$ & $\mathrm{S}_{6}(59), \mathrm{S}_{23}(28)$ \\
\hline$v\left(\mathrm{C}-\mathrm{C}_{\alpha}\right)$ & $A^{\prime}$ & 1245.4 & 185.0 & $1268.4 / 1266.6$ & $\mathrm{~S} / \mathrm{S}$ & $\mathrm{S}_{2}(34), \mathrm{S}_{3}(12)$ \\
\hline$\delta(\mathrm{C}-\mathrm{H}$ ring 4$)$ & $A^{\prime}$ & 1174.3 & 15.9 & 1180.1 & $\mathrm{~m}$ & $\mathrm{~S}_{26}(74), \mathrm{S}_{5}(23)$ \\
\hline$\delta(\mathrm{C}-\mathrm{H}$ ring 5$)$ & $A^{\prime}$ & 1157.7 & 0.7 & 1150.8 & w & $S_{27}(65), S_{6}(12), S_{25}(13)$ \\
\hline$v(\mathrm{C}-\mathrm{C}$ ring 6$)$ & $\mathrm{A}^{\prime}$ & 1081.7 & 6.3 & 1088.6 & $\mathrm{w}$ & $\mathrm{S}_{9}(50), \mathrm{S}_{25}(32)$ \\
\hline$v(\mathrm{C}-\mathrm{C}$ ring 5$)$ & $A^{\prime}$ & 1068.8 & 1.7 & 1077.7 & $\mathrm{w}$ & $\mathrm{S}_{8}(18), \mathrm{S}_{39}(25), \mathrm{S}_{24}(12), \mathrm{S}_{15}(11)$ \\
\hline$v(\mathrm{C}-\mathrm{C}$ ring 1$)$ & $\mathrm{A}^{\prime}$ & 1021.9 & 6.1 & 1024.7 & $\mathrm{w}$ & $S_{4}(23), S_{8}(40), S_{24}(17), S_{15}(16)$ \\
\hline$\gamma \mathrm{CH}_{3}$ & $A^{\prime \prime}$ & 1021.6 & 0.5 & 1015.0 & $\mathrm{w}$ & $\mathrm{S}_{40}(60), \mathrm{S}_{42}(25)$ \\
\hline$\delta($ ring 1$)$ & $\mathrm{A}^{\prime}$ & 994.5 & 0.8 & 996.7 & $\mathrm{w}$ & $\mathrm{S}_{15}(56), \mathrm{S}_{4}(44)$ \\
\hline$\gamma(\mathrm{C}-\mathrm{H}$ ring 5$)$ & $A^{\prime \prime}$ & 990.4 & 0.3 & 990.9 & $\mathrm{w}$ & $\mathrm{S}_{32}(51), \mathrm{S}_{18}(20), \mathrm{S}_{31}(14)$ \\
\hline$\gamma(\mathrm{C}-\mathrm{H}$ ring 4$)$ & $\mathrm{A}^{\prime \prime}$ & 975.7 & 0.3 & 969.8 & w & $\mathrm{S}_{31}(54), \mathrm{S}_{20}(20), \mathrm{S}_{32}(10)$ \\
\hline$\gamma \mathrm{CH} 3$ & $A^{\prime}$ & 935.1 & 35.0 & 953.3 & $\mathrm{~m}$ & $\mathrm{~S}_{39}(38), \mathrm{S}_{3}(33), \mathrm{S}_{43}(10)$ \\
\hline$\gamma(\mathrm{C}-\mathrm{H}$ ring 3$)$ & $A^{\prime \prime}$ & 926.1 & 2.5 & 948.0 & $\mathrm{w}$ & $S_{30}(67), S_{19}(10)$ \\
\hline$\gamma(\mathrm{C}-\mathrm{H}$ ring 2$)$ & $A^{\prime \prime}$ & 843.8 & 0.3 & 826.9 & $\mathrm{w}$ & $\mathrm{S}_{29}(98)$ \\
\hline$\gamma(\mathrm{C}-\mathrm{H}$ ring 1$)$ & $A^{\prime \prime}$ & 757.6 & 40.3 & $757.7 / 755.2$ & $\mathrm{~m} / \mathrm{m}$ & $\mathrm{S}_{28}(58), \mathrm{S}_{22}(19)$ \\
\hline$\delta(\operatorname{ring} 3)$ & $\mathrm{A}^{\prime}$ & 724.9 & 0.6 & 742.9 & $\mathrm{w}$ & $S_{17}(36), S_{2}(20), S_{3}(15)$ \\
\hline$\delta(\operatorname{ring} 1)$ & $A^{\prime \prime}$ & 688.1 & 39.9 & 687.6 & $\mathrm{~S}$ & $\mathrm{~S}_{18}(44), \mathrm{S}_{28}(26), \mathrm{S}_{32}(20)$ \\
\hline$\delta($ ring 2$)$ & $\mathrm{A}^{\prime}$ & 618.0 & 1.0 & $649.3 / 636.5$ & $\mathrm{w} / \mathrm{w}$ & $\mathrm{S}_{16}(88)$ \\
\hline$\gamma(\mathrm{C} 1=\mathrm{O})$ & $\mathrm{A}^{\prime \prime}$ & 587.4 & 12.0 & 590.5 & $\mathrm{~m}$ & $S_{42}(42), S_{40}(18), S_{18}(10), S_{22}(10)$ \\
\hline$v\left(\mathrm{C}-\mathrm{CH}_{3}\right)$ & $\mathrm{A}^{\prime}$ & 583.1 & 25.5 & $587.1 / 584.2$ & $\mathrm{~m} / \mathrm{m}$ & $S_{3}(18), S_{43}(48), S_{17}(20)$ \\
\hline$\delta\left(\mathrm{C}_{1}=\mathrm{O}\right)$ & $A^{\prime}$ & 454.4 & 0.8 & n.i. & & $S_{43}(15), S_{44}(27), S_{21}(15), S_{17}(13)$ \\
\hline$\gamma($ ring $)$ & $\mathrm{A}^{\prime \prime}$ & 418.5 & 0.3 & n.i. & & $S_{22}(31), S_{19}(38), S_{42}(15)$ \\
\hline$\tau(\operatorname{ring} 3)$ & $A^{\prime \prime}$ & 403.2 & 0.0 & n.i. & & $\mathrm{S}_{20}(71), \mathrm{S}_{31}(25)$ \\
\hline$\delta\left(\mathrm{CC}_{1} \mathrm{C}\right)$ & $A^{\prime}$ & 356.7 & 0.7 & n.i. & & $\mathrm{S}_{44}(50), \mathrm{S}_{2}(24), \mathrm{S}_{17}(21)$ \\
\hline$\omega($ ring $)$ & $\mathrm{A}^{\prime}$ & 212.2 & 5.3 & n.i. & & $\mathrm{S}_{21}(64), \mathrm{S}_{43}(21)$ \\
\hline$\tau($ ring 2$)$ & $\mathrm{A}^{\prime \prime}$ & 150.0 & 0.0 & n.i. & & $\mathrm{S}_{19}(41), \mathrm{S}_{22}(28)$ \\
\hline$\tau \mathrm{CH}_{3}$ & $\mathrm{~A}^{\prime \prime}$ & 142.8 & 0.0 & n.i. & & $\mathrm{S}_{41}(95)$ \\
\hline$\tau\left(\mathrm{C}-\mathrm{C}_{\alpha}\right)$ & $A^{\prime \prime}$ & 52.5 & 3.9 & n.i. & & $\mathrm{S}_{45}(98)$ \\
\hline
\end{tabular}

${ }^{a}$ Wavenumbers in $\mathrm{cm}^{-1}$, calculated intensities in $\mathrm{km} \mathrm{mol}^{-1}, v$, bond stretching, $\delta$, bending, $\gamma$, rocking, $\omega$, wagging, $\tau$, torsion, n.o., not observable, n.i., not investigated. See Table S4 (Supporting Material) for definition of internal coordinates. Only approximated bands assigned to fundamental modes are presented in the table. ${ }^{b}$ Only PED values greater than $10 \%$ are given. ${ }^{c}$ Scaled $(0.978) .{ }^{d}$ Experimental intensities are presented in qualitative terms: $\mathrm{S}=$ strong, $\mathrm{m}=$ medium; $\mathrm{w}=$ weak.

and recombination of the methyl radical resulting from this process with the benzoyl radical occurs, leading to production of acetophenone. This mechanism is also supported by the absence of any band in the irradiated spectra that could be assigned to toluene (the expected final product of recombination of $\mathrm{CH}_{3}$ and phenyl radicals). Very interestingly, the proposed mechanism of decarbonylation shall lead exclusively to production of $\mathrm{CO}$ originated from the acetyl moiety. Hence, its definitive confirmation can be done by analysis of the photoproducts obtained by photolysis of PPD isotopomers labeled with ${ }^{13} \mathrm{C}$ or ${ }^{18} \mathrm{O}$ either in the acetyl or benzoyl group. The experimental procedure applied to the study of isotopically labeled PPD should be the same as that used in the present study.

After identifying the products of irradiation, a kinetic analysis of the reaction was performed. From the rate of disappearance of the bands corresponding to the reagent and simultaneous increase of bands corresponding to the photoproducts, a rate constant for the unimolecular primary photodecomposition process under the present experimental conditions was estimated (Figure 9), yielding $k=2.8 \times 10^{-2} \mathrm{~min}^{-1}$.

\section{Conclusion}

1-Phenyl-1,2-propanedione was, for the first time, isolated in xenon matrixes, and its molecular structure and vibrational signature probed by FTIR spectroscopy, supported by DFT(B3LYP)/6-311++G(d,p) calculations. The structural results, obtained in the present work, correlate nicely with the ones obtained in the gaseous phase by electron diffraction ${ }^{43}$ and demonstrate the importance of the large amplitude, lowfrequency torsional vibration about the intercarbonyl $\mathrm{C}-\mathrm{C}$ bond $(\tau \mathrm{C}-\mathrm{C})$ in determining the structural and vibrational properties exhibited by this compound. The experimental data clearly reveals that, in the as-deposited xenon matrixes $(T=20 \mathrm{~K})$, there is a distribution of molecules with different $\mathrm{O}=\mathrm{C}-\mathrm{C}=\mathrm{O}$ dihedral angles around the equilibrium value $\left(135.6^{\circ}\right)$. This 


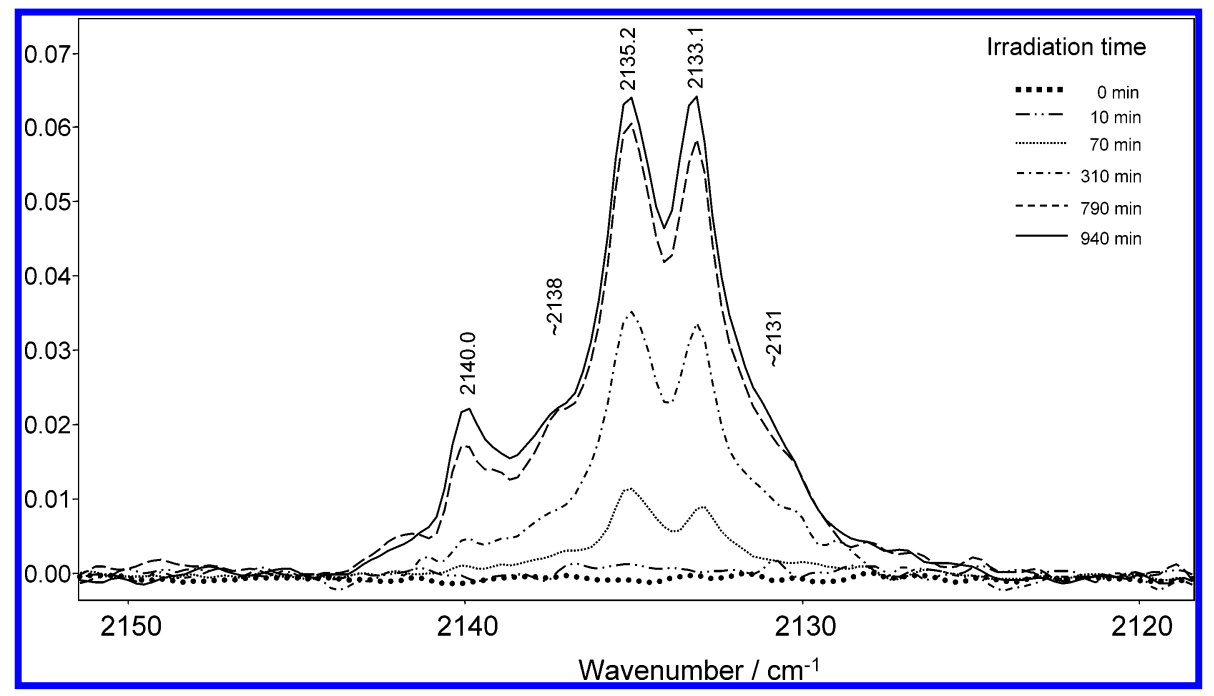

Figure 8. $v \mathrm{CO}$ spectral range as function of the irradiation time.

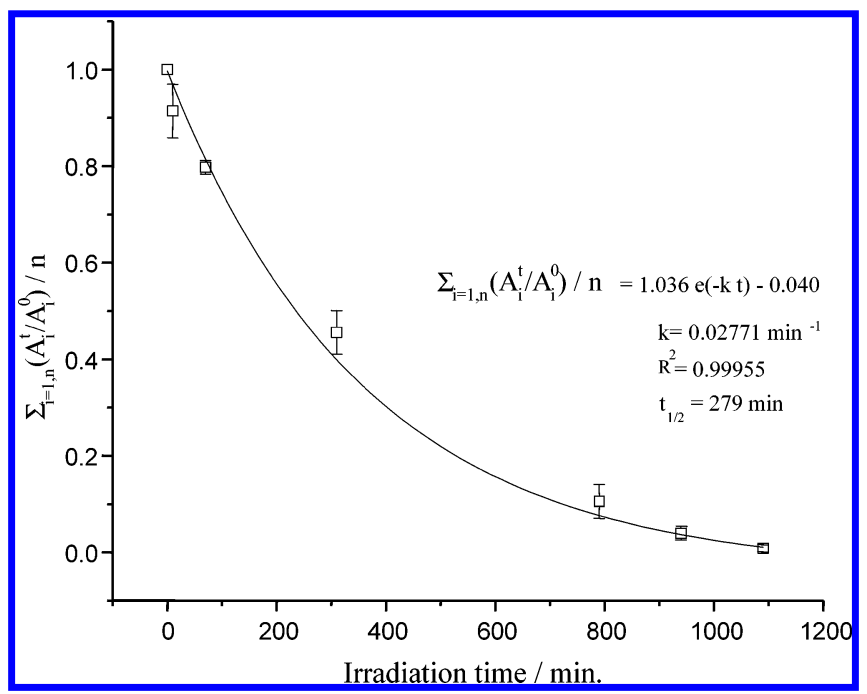

Figure 9. Plot of the average value ( \pm standard deviation) of the ratios between the absorption of the PPD bands in the spectra of the irradiated matrix at a given time $\left(A_{i}^{\mathrm{t}}\right)$ and the absorption of the same bands in the nonirradiated matrix $\left(A_{i}^{0}\right)$. The subscript $i$ refers to a given band of PPD and $\mathrm{n}$ correspond to the number of bands used in the calculations, which was equal to 4 . The bands used $(1716.9,1677.0, \sim 1353$, and $1188.7 \mathrm{~cm}^{-1}$ ) were selected among the most intense bands of PPD that do not show overlapping with bands due to the photoproducts.

distribution results from the efficient trapping of the conformational distribution existing in the gas phase, prior to deposition, which is determined by the $\tau \mathrm{C}-\mathrm{C}$ torsion. Upon annealing to higher temperatures $(T \sim 45 \mathrm{~K})$, the initially trapped conformational distribution changes toward more polar structures (corresponding to smaller $\mathrm{O}=\mathrm{C}-\mathrm{C}=\mathrm{O}$ dihedral angles), as a result of conformational cooling and of interactions with the matrix media. In the neat amorphous solid resulting from fast deposition of the vapor of the compound (at $298 \mathrm{~K}$ ) onto a cooled CsI substrate kept at $9 \mathrm{~K}$, the existing distribution of conformations was also found to be enriched in more polar conformations with smaller $\mathrm{O}=\mathrm{C}-\mathrm{C}=\mathrm{O}$ dihedral angles, when compared with the gas phase. These results follow closely previous data obtained for similar compounds, such as diacetyl and benzil. ${ }^{38,39}$

Irradiation of PPD with UV light $(\lambda>235 \mathrm{~nm})$, yields CO and acetophenone. The $\mathrm{CO}$ molecules result probably from a secondary photoprocess in which the initially photoproduced acetyl radical, generated by cleavage of the PPD intercarbonyl
$\mathrm{C}-\mathrm{C}$ bond, decomposes to $\mathrm{CH}_{3}$ and $\mathrm{CO}$. In the matrix cage, the methyl radical can then recombine with the most stable benzoyl radical formed in the primary photoprocess. The $\mathrm{CO}$ molecules may either be kept in the matrix cage forming a complex with acetophenone or diffuse through the matrix, being identified spectroscopically as isolated monomers, as $\mathrm{CO}$ homoaggregates or complexed with $\mathrm{H}_{2} \mathrm{O}$ existing in the matrix as trace-impurity.

Acknowledgment. This work was funded by Fundação para a Ciência e a Tecnologia (FCT-Projects POCTI/QUI/59019/2004 and POCTI/QUI/58937/2004), Portugal, FEDER, CONICET and Agencia Nacional de Promoción Científica y TecnológicaPICT 13080.

Supporting Information Available: Figures S1-S3 and Tables S1-S4. This material is available free of charge via the Internet at http://pubs.acs.org.

\section{References and Notes}

(1) Miller, A. G.; Meade, S. J.; Gerrard, J. A. Bioorg. Med. Chem 2003, 11, 843 .

(2) Meade, S. J.; Miller, A. G.; Gerrard, J. A. Bioorg. Med. Chem. 2003, 11, 853.

(3) Kida, T.; Michinobu T.; Zhang, W.; Nakatsuji, Y.; Ikeda, I. Chem. Commun. (Camb.) 2002, 7, 1596.

(4) Fan, X.; Subramaniam, R.; Weiss, M. F.; Monnier, V. M. Arch. Biochem. Biophvs. 2003, 409, 274.

(5) Asmussen, E.; Peutzfeldt, A. Acta Odontol. Scand. 2002, 60, 146.

(6) Park, Y.-J.; Chae, K.-H.; Rawls, H. R. Dent. Mater. 1999, 15, 120.

(7) Sun, G.; Chae, K. Polvmer 2000, 41, 6205.

(8) Bibaut-Renauld, C.; Burget, D.; Fouassier, J. P.; Varelas, C. G.; Thomatos, J.; Tsagaropoulos, G.; Ryfors, L. O.; Karlsson, O. J. J. Polym. Sci. A. 2002, 40, 3171.

(9) Toukoniitty, E.; Mäki-Arvela, P.; Kuusisto, J.; Nieminen, V.; Päivärinta, J.; Hotokka, M.; Salmi, T.; Murzin, D. Y. J. Mol. Catal. A 2003, 192, 135.

(10) Toukoniitty, E.; Mäki-Arvela, P.; Nieminen, V.; Salmi, T.; Murzin, D. Y. Kinet. Catal. 2003, 44, 562.

(11) Toukoniitty, E.; Mäki-Arvela, P.; Kumar, N.; Salmi, T.; Murzin, D. Y. Catal. Today 2003, 79-80, 189.

(12) Toukoniitty, E.; Wärna, J.; Salmi, T.; Mäki-Arvela, P.; Murzin, D. Y. Catal. Today 2003, 79-80, 383.

(13) Toukoniitty, E.; Mäki-Arvela, P.; Wärna, J.; Salmi, T. Catal. Todav 2001, 66, 411.

(14) Toukoniitty, E.; Mäki-Arvela, P.; Sjöholm, R.; Leino, R.; Salmi, T.; Murzin D. Y. React. Kinet. Catal. Lett. 2002, 75, 21.

(15) Toukoniitty, E.; Mäki-Arvela, P.; Kuzma, M.; Villela, A.; Neyestanaki, A. K.; Salmi, T.; Sjöholm, R.; Leino, R.; Laine, E.; Murzin, D. Y. J. Catal. 2001, 204, 281.

(16) Toukoniitty, E.; Mäki-Arvela, P.; Neyestanaki, A. K.; Laine, E.; Mikkola, J. P.; Salmi, T.; Murzin, D. Y. React. Kinet. Catal. Lett. 2001 73,3 . 
(17) Mikkola, J. P.; Toukoniitty, B.; Toukoniitty, E.; Aumo, J.; Salmi, T. Ultrasonics Sonochem. 2004, 11, 233.

(18) Toukoniitty, B.; Toukoniitty, E.; Mäki-Arvela, P.; Mikkola, J. P.; Salmi, T.; Murzin, D. Y.; Kooyman, P. J. Ultrasonics Sonochem. 2005 in press.

(19) Toukoniitty, E.; Mäki-Arvela, Neyestanaki, A. K.; Salmi, T.; Sjöholm, R.; Leino, R.; Laine, E.; Kooyman, P. J.; Ollonqvist, T.; Väryrynen, J. Appl. Catal. A: General 2001, 216, 73 .

(20) Hess, R.; Maillat, T.; Baiker, A. J. Catal. 2003, 218, 453.

(21) Park, J. W.; Hong, M. J.; Park, K. K. Bull. Korean Chem. Soc. 2001, 22, 1213

(22) Kreutz, O. C.; Moran, P. J. S.; Rodrigues, J. A. R. TetrahedronAsvm. 1997, 8, 2649.

(23) Sorrilha, A. E. P. M.; Marques, M.; Joekes, I.; Moran, P. J. S.; Rodrigues, J. A. R. Bioorg. Med. Chem. Lett. 1992, 2, 191

(24) Brenelli, E. C. S.; Moran, P. J. S.; Rodrigues, J. A. R. Synth. Commun. 1990, 20, 261.

(25) Takeshita, M.; Sato, T. Chem. Pharm. Bull. 1989, 37, 1085.

(26) Segretario, J. P.; Zuman, P. J. Electroanal. Chem. 1986, 214, 237.

(27) Prelusky, D. B.; Coutts, R. T.; Pasutto, F. M. J.P Parm. Sci. 1983, 71,1390 .

(28) Shukala, V. B.; Kulkarni, P. R. J. Microbiol. Biotechnol. 2000 16,499

(29) Rosche, B.; Sandford, V.; Breuer, M.; Rogers, P. Appl. Microbiol. Technol. 2001, 57, 309.

(30) Gala, D.; DiBenedetto, D.; Clark, J.; Murphy, B.; Schumacher, D.; Steinman, M. Tetrahedron Lett. 1996, 37, 611

(31) Nishimura, T.; Kitajima, K. J. Org. Chem. 1976, 41, 1590

(32) Pawlikowski, M.; Zgierski, M.; Orlandi, G. Chem. Phvs. Lett. 1984 105,612 . 754

(33) Bera, S.; Mukherjee, R.; Choudhury, M. J. Chem. Phys. 1969, 51,

(34) Morantz, D.; Wright, A. J. Chem. Phys. 1971, 54, 692.

(35) Bera, S.; Mukherjee, R.; Mukherjee, D.; Choudhury, M. J. Chem. Phvs. 1971, 55, 5826

(36) Arnett, J.; McGlynn, S. J. Phvs. Chem. 1975, 79, 626.

(37) Arnett, J.; Newkome, G.; Mattice, W.; McGlynn, S. J. Am. Chem.

Soc. 1974, 96, 4385.

(38) Gómez-Zavaglia, A.; Fausto R. J. Mol. Struct. 2003, 661-662, 195

(39) Lopes, S.; Gómez-Zavaglia, A.; Lapinski, L.; Chattopadhayay, N.;

Fausto, R. J. Phvs. Chem. A 2004, 108, 8256.

(40) Sing, A.; Palit, D.; Mittal, J. Chem. Phvs. Lett. 2002, 360, 443. 62,3

(42) Das, K.; Majundar, D. J. Mol. Struct. 1993, 288, 55.

(43) Shen, Q.; Hagen, K. J. Phvs. Chem. 1993, 97, 985.

(44) Evans, T.; Leermakers, P. J. Am. Chem. Soc. 1967, 89, 4380.

(45) Leonard, N.; Mader, P. J. Am. Chem. Soc. 1950, 72, 5388.

(46) Leonard, N.; Rapala, T.; Herzog, H.; Blout, E. J. Am. Chem. Soc.

1949, 71, 2997.

(47) Leonard, N.; Blout, E. J. Am. Chem. Soc. 1950, 72, 484. $(48)$

(49) Danielson, D.; Hedberg, K. J. Am. Chem. Soc. 1979, 101, 3730

(50) Shen, Q.; Hagen, K. J. Phvs. Chem. 1987, 91, 1357.

(51) Griffin, J.; Playe, S.; Osborne, B.; Smithline, H. BMC Emerg. Med 2004, 4,4 .

(52) Cobb, N.; Etzel, R. A. Jama 1991, 266, 659.

(53) Litovitz, T. L.; Holm, K. C.; Bailey, K. M.; Schmitz, B. F. Am. J. Emerg. Med. 1992, 10, 452.

(54) Omaye, S. Toxicology 2002, 180, 139.

(55) Reva, I.; Stepanian, S.; Adamowicz, L.; Fausto, R. J. Phys. Chem. A 2001, 105, 4773.
(56) Frisch, M.; Trucks, G.; Schlegel, H.; Scuseria, G.; Robb, M.; Cheeseman, J.; Zakrzewski, V.; Montgomery, J.; Stratmann, R.; Burant, K.; Dapprich, S.; Millam, J.; Daniels, A.; Kudin, K.; Strain, M.; Farkas, O.; Tomasi, J.; Barone, V.; Cossi, M.; Cammi, R.; Mennucci, B.; Pomelli, C.; Adamo, C.; Clifford, S.; Ochterski, J.; Petersson, G.; Ayala, P.; Cui, Q.; Morokuma, K.; Malick, D.; Rabuck, A.; Raghavachari, K.; Foresman, J.; Cioslowski, J.; Ortiz, J.; Baboul, A.; Stefanov, B.; Liu, G.; Liashenko, A.; Piskorz, P.; Komaromi, I.; Gomperts, R.; Martin, R.; Fox, D.; Keith, T.; Al-Laham, M.; Peng, C.; Nanayakkara, A.; Challacombe, M.; Gill, P.; Johnson, B.; Chen, W.; Wong, M.; Andres, J.; Gonzalez, C.; Head-Gordon, M.; Replogle, S.; Pople, J. Gaussian 98, revision A.9; Gaussian Inc.: Pittsburgh, PA, 1998

(57) Becke, A. D. Phys. Rev. A. 1988, 38, 3098

(58) Lee, C. T.; Yang, W. T.; Parr, R. G. Phvs. Rev. B 1988, 37, 785.

59) Csaszar, P.; Pulay, P. J. Mol. Struct. (THEOCHEM) 1984, 114

(60) Schachtschneider, J. H. Technical Report; Shell Development Co: Emeryville, CA, 1969

(61) Fausto, R.; Teixeira-Dias, J. J. C.; Carey, P. R. J. Mol. Struct.(THEOCHEM) 1988, 168, 179.

(62) Fausto, R.; Batista de Carvalho, L. A. E.; Teixeira-Dias, J. J. C. J. Mol. Struct. (THEOCHEM) 1990, 207, 67.

(63) Noyes Jr., W. A., Porter, G. B.; Jolley, J. F. Chem. Rev. 1956, 56 , 49.

(64) Simbürger, H.; Kern, W.; Hummel, K.; Hagg, C. Polvmer 2000 , 41,7883 .

(65) Adam, W.; Kita, F.; Oestrich, R. S. J. Photochem. Photobiol. A 1994, 80, 187. 2179

(66) McGimpsey, W. G.; Scaiano, J. C. J. Am. Chem. Soc. 1987, 109,

(67) Chupka, W. A.; Liftshitz, C. J. Chem. Phvs. 1968, 48, 1109

(68) McMillen, D. F.; Golden, D. M. Annu. Rev. Phys. Chem. 1982 $33,493$.

(69) Zhao, H. Q.; Cheung, Y. S.; Liao, C. L.; Liao, C. X.; Ng, C. Y.;

Li, W. K. J. Chem. Phvs. 1997, 107, 7230.

(70) Hole, K. J.; Mulcahy, M. F. R. J. Phvs. Chem. 1969, 73, 177.

(71) Murad, E.; Inghram, M. J. Phys. Chem. 1964, 41, 404.

(72) Reva, I. D.; Ilieva, S. V.; Fausto, R. Phvs. Chem. Chem. Phvs. 2001, 3, 4235 .

(73) Reva, I. D.; Stepanian, S. G.; Adamowicz, L.; Fausto, R. Chem. Phvs. Lett. 2003, 4374, 631.

(74) Lee, K. O. Can. J. Phvs. 1971, 49, 2018.

(75) Duvernay, F.; Chiavassa, T.; Borget, F.; Aycard, J. P. Chem. Phvs 2004, 298, 241

(76) Dubost, H.; Marguin, L. A. Chem. Phys. Lett. 1972, 17, 269

(77) Diau, E. W. G.; Kötting, C.; Sølling, T. I.; Zewail, A. H. Chem. Phvs. Chem. 2002, 3, 57 .

(78) Diau, E. W. G.; Kötting, C.; Zewail, A. H. Chem. Phvs. Chem 2001, 2, 273.

(79) Solly, R. K.; Benson, S. W. J. Am. Chem. Soc. 1971, 93, 2117.

(81) Mao, W.; Li, Q.; Kong, F.; Huang, M. Chem. Phys. Lett. 1998 283,114

(82) Adachi, H.; Basco, N.; James, D. G. L. Chem. Phvs. Lett. 1978, 59,502 .

(83) Parkes, D. A. Chem. Phvs. Lett. 1981, 77, 527.

(84) Kerr, J. A.; Calvert, J. G. J. Phys. Chem. 1965, 69, 1022

(85) Li, H.; Li, Q.; Mao, W.; Zhu, Q.; Kong, F. J. Chem. Phvs. 1997, 106,5943

(86) Núñez, E. M.; Vázquez, S. A. Chem. Phys. Lett. 2000, 316, 471 